\title{
No Good Deed Goes Unpunished: Charitable Contributions and the Foreign Corrupt Practices Act
}

William Nelson

Follow this and additional works at: https://via.library.depaul.edu/bclj

\section{Recommended Citation}

William Nelson, No Good Deed Goes Unpunished: Charitable Contributions and the Foreign Corrupt Practices Act, 11 DePaul Bus. \& Com. L.J. 331 (2013)

Available at: https://via.library.depaul.edu/bclj/vol11/iss3/3

This Article is brought to you for free and open access by the College of Law at Digital Commons@DePaul. It has been accepted for inclusion in DePaul Business and Commercial Law Journal by an authorized editor of Digital Commons@DePaul. For more information, please contact digitalservices@depaul.edu. 


\title{
No Good Deed Goes Unpunished: Charitable Contributions and the Foreign Corrupt Practices Act
}

\author{
William Nelson*
}

\section{CONTEnTs}

I. IntRodUCtION.................................... 332

II. Foreign Corrupt Practices Act .............. 333

A. Background of the FCPA .................. 333

B. Provisions of the FCPA ................... 334

1. Anti-Bribery Provisions.................. 334

a. "Corrupt" Intent.................... 335

b. "Anything of Value" ................. 336

c. "Knowledge" Requirement .............. 336

d. "Foreign Official".................... 337

e. "Obtain or Retain" Business ............ 339

2. Record-Keeping Provisions ................ 339

3. Exceptions and Affirmative Defenses......... 339

4. Enforcement and Penalties ................ 340

III. Charitable Giving and the FCPA ............. 341

A. In re Schering-Plough ...................... 341

B. Wynn Resorts ........................... 345

C. DOJ FCPA Opinion Procedure Releases.......... 346

1. FCPA Opinion Procedure Release 95-01 ..... 348

2. FCPA Opinion Procedure Release 97-02 ..... 348

3. FCPA Opinion Procedure Release 06-01 ..... 349

4. FCPA Opinion Procedure Release 09-01 ..... 350

5. FCPA Opinion Procedure Release 10-02 ..... 352

D. What We Have Learned..................... 354

1. No Officials of the Charity Affiliated with Foreign Government................... 355

2. Payments Made Directly to Foreign Government ....................... 356

3. Control and Monitoring of Charitable Contributions .......................... 357

* Professorial Lecturer in Law, George Washington University Law School; Public Policy Counsel, Certified Financial Flanner Board of Standards, Inc.; Managing Associate Editor, Wealth Strategies Journal; Member, Legal Writing Institute. 
4. "Compelled Giving" Laws ................. 357

IV. Corporate Social Responsibility ............... 359

A. The FCPA's Effect on Charitable Contributions..... 360

B. Companies Using Corporate Social Responsibility to Disguise Bribery ............................. 362

1. "Corrupt" Intent.................... 362

2. Anti-Bribery v. Record-Keeping Provisions..... 363

3. Contributions to Domestic Charity Involved in Charitable Foreign Activities ............... 364

4. Corporate Social Responsibility Used to Disguise Bribery: Hypothetical Situations...... 365

V. Minimizing Liability ............................... 369

A. FCPA Compliance Program ................. 369

1. Proposed Model for Charitable Contribution Compliance Programs ..................... 370

a. Elements ........................ 370

b. Charitable Contributions Compliance Committee......................... 374

c. Whistleblower Protection Program ........ 375

B. Due Diligence............................. 376

VI. Conclusion ................................... 378

\section{INTRODUCTION}

The Foreign Corrupt Practices Act (FCPA) was signed into law in December of 1977.1 Congress believed that the corporate bribery scandals during the early 1970s shook public confidence in American corporations. ${ }^{2}$ Following inquiries by the U.S. Senate and the Securities and Exchange Commission (SEC), ${ }^{3}$ Congress-concerned that the disclosure of these dishonest corporate practices would seriously undermine public confidence in the American business communityenacted the FCPA. ${ }^{4}$

1. Foreign Corrupt Practices Act of 1977, Pub. L. No. 95-213, 91 Stat. 1,494 (codified as amended in scattered sections of 15 U.S.C.).

2. Pamela J. Jadwin \& Monica Shilling, Foreign Corrupt Practices Act, 31 Am. Crim. L. Rev. 677,677 (1994). An example of corruption for which the FCPA was enacted to curtail was a $\$ 1.4$ million bribe that Lockheed gave to the Prime Minister of Japan, resulting in his conviction and imprisonment. Id. at 677 n.3. Also, "payments by Lockheed, Exxon, Mobil, Gulf and other corporations to the Italian Government caused the Italian President to resign and strained United States relations with Italy." Laura E. Longobardi, Reviewing the Situation: What Is to Be Done with the Foreign Corrupt Practices Act?, 20 Vand. J. Transnat'L L. 431, 433 (1987).

3. Jadwin \& Shilling, supra note 2 , at $677-78$.

4. $I d$. at $677 \mathrm{n} .4$ (noting that "[o]f 97 companies listed in the final SEC report, 77 admitted to or were suspected of questionable or outright illegal payments to foreign political or commercial interests"). 
This Article examines the effect of the FCPA on companies' contributions to charitable organizations. Part II reviews the background of the FCPA and discusses the elements of an FCPA violation. Congress tasked two agencies, the Department of Justice (DOJ) and the SEC, with authority to enforce the FCPA. Part III examines the SEC's recent civil enforcement action concerning charitable giving under the FCPA. It also analyzes a handful of advisory opinions issued by the DOJ regarding charitable giving and the FCPA. Part IV considers corporate social responsibility (CSR) in the context of FCPA enforcement. It provides hypothetical situations illustrating companies' use of CSR to disguise acts of bribery and examines any chilling effect that the FCPA has on companies' charitable giving. Part V proposes a model FCPA compliance program, including the creation of a Charitable Contributions Compliance Committee (CCCC), to address charitable donations as an area of risk. It also provides a roadmap of the due diligence required to minimize liability under the FCPA for companies making charitable contributions.

\section{Foreign Corrupt Practices Act}

\section{A. Background of the FCPA}

During the Watergate investigation into President Nixon's campaign contributions, a widespread practice of bribery by U.S. companies to obtain business in foreign countries was uncovered. ${ }^{5}$ Politicians feared that this practice would "undermine[ ] public confidence in the business community and tarnish[] America's image abroad."6

For example, the Prime Minister of Japan was forced to resign after he accepted payments from Lockheed Corp. ${ }^{7}$ Reports also showed that Lockheed Corp. paid Prince Bernhardt of the Netherlands \$1 mil-

5. See Barbara Crutchfield George et al., On the Threshold of the Adoption of Global Antibribery Legislation: A Critical Analysis of Current Domestic and International Efforts Toward the Reduction of Business Corruption, 32 Vand. J. TRANSNAT'L L. 1, 5 (1999); see also S. ReP. No. 95-114, at 3 (1977), reprinted in 1977 U.S.C.C.A.N. 4,098, 4,101 (noting that SEC investigations at the time of the report revealed corrupt payments by over 300 U.S. companies involving hundreds of millions of dollars); Thomas McSorley, Foreign Corrupt Practices Act, 48 AM. CRIM. L. REv. 749, $750 \mathrm{n} .2$ (2011) (noting that "[t]he FCPA is also the byproduct of the Watergate Scandal: after discovering unreported campaign contributions, the SEC initiated an investigation into payments to domestic and foreign political officials by corporations").

6. Jadwin \& Shilling, supra note 2, at 678.

7. Id. at 677. "Prime Minister Kakuei Tanaka, and other high government officials were toppled from power amid revelations of approximately $\$ 12$ million in illegal payoffs from the Lockheed corporation, which were paid since the [1950s] to secure airplane sales contracts from the Japanese government." Bruce A. Gragert, Yakuza: The Warlords of Japanese Organized Crime, 4 AnN. Surv. InT'L \& Comp. L. 147, 160 (1997). 
lion, and the ensuing scandal eventually compelled him to relinquish his official functions. ${ }^{8}$ The extensive media coverage of these events led the SEC to investigate a number of companies and to institute a voluntary disclosure program. ${ }^{9}$

The FCPA was enacted "to bring ... corrupt practices to a halt and to restore public confidence in the integrity of the American business system."10 A 1977 Senate Report, discussing the enactment of the FCPA, stated that "[c]orporate bribery is bad business."11 This report, along with the reports of widespread corrupt payments by corporations, reflects why the FCPA was needed to curb corporate bribery and restore the confidence of investors in America and abroad. ${ }^{12}$

\section{B. Provisions of the FCPA}

The FCPA is composed of "accounting and record-keeping provisions" and "anti-bribery provisions." 13

\section{Anti-Bribery Provisions}

The FCPA's anti-bribery provisions, found in 15 U.S.C. $\S \S 78 \mathrm{dd}-1$, $78 \mathrm{dd}-2$, and $78 \mathrm{dd}-3,{ }^{14}$ prohibit "any promise, offer, or payment of anything of value if the offeror 'knows' that any portion will be offered, given, or promised to a foreign official, foreign political party, or candidate for public office for the purpose of influencing a governmental decision." 15

8. Longobardi, supra note 2 , at 433.

9. Id. "In the 1970 s, the SEC announced its voluntary disclosure program concerning the suspected widespread practice of public companies maintaining off the books slush funds, which were used to make payments ... [to] government officials in business transactions." William R. McLucas et al., The Decline of the Attorney-Client Privilege in the Corporate Setting, 96 J. CRIM. L. \& CRIMINOLOGY 621, 624 (2006) (footnote omitted) (internal quotation marks omitted). "The results were stunning: Hundreds of [U.S.] corporations came forward with disclosures about the existence of such funds and the use of these off the books accounts to facilitate all manner of questionable payments." Id. (internal quotation marks omitted).

10. S. REP. No. 95-114, at 4.

11. Id.

12. William Alan Nelson II, Attorney Liability Under the Foreign Corrupt Practices Act: Legal and Ethical Challenges and Solutions, 39 U. MEM. L. REV. 255, 258 n.11 (2009).

13. Stuart H. Deming, The Potent and Broad-Ranging Implications of the Accounting and Record-Keeping Provisions of the Foreign Corrupt Practices Act, 96 J. CRIM. L. \& CRIMINOLOGY 465, 467 (2006).

14. See 15 U.S.C. $\S \S 78 \mathrm{dd}-1$ to $78 \mathrm{dd}-3$ (2006) (internal quotation marks omitted).

15. Deming, supra note 13 , at 467 (citing 15 U.S.C. $\S 78 \mathrm{dd}-1$ to $78 \mathrm{dd}-3$ ). 


\section{a. "Corrupt" Intent}

For a payment to violate the FCPA, it must be given "corruptly." 16 The term corruptly is not specifically defined in the FCPA, but the legislative history of the FCPA provides some guidance. The legislative history signifies that Congress viewed the term corruptly to connote an action that was done with a bad intent. ${ }^{17}$ In a 1977 House Report, ${ }^{18}$ Congress stated that the word corruptly in the FCPA was intended to have the same meaning as in 18 U.S.C. $\& 201$, which is the federal statute criminalizing the bribing of a federal official. ${ }^{19}$

United States $v$. Liebo is the seminal case that analyzes the meaning of the term corruptly under the FCPA. ${ }^{20}$ In Liebo, the defendant, Liebo, was convicted for violating the FCPA because he gave a Niger government official airline tickets for his honeymoon in order to influence another official who was the relative and friend of the Niger official. ${ }^{21}$ The court found that there was sufficient evidence that these "tickets were given to obtain or retain business." 22 The relevant evidence included the fact that Liebo classified the airline ticket as a "commission payment" for accounting purposes, ${ }^{23}$

The district court judge instructed the jury:

[T] he offer, promise to pay, payment or authorization of payment, must be intended to induce the recipient to misuse his official position or to influence someone else to do so, and that an act is corruptly done if done voluntarily [a]nd intentionally, and with a bad

16. See David P. Burns \& Erin K. Sullivan, Navigating the FCPA's Complex Scienter Requirements, GiBson DunN (Apr. 1, 2009), http://www.gibsondunn.com/publications/Documents/ Burns-Sullivan-NavigatingTheFCPAComplexScienterReq.pdf.

17. See Steven R. Salbu, Bribery in the Global Market: A Critical Analysis of the Foreign Corrupt Practices Act, 54 WAsh. \& Lee L. Rev. 229, 245 (1997).

18. H.R. Rep. No. $95-640$ (1977).

19. Id. at 7. The statute states whoever "directly or indirectly, corruptly gives, offers or promises anything of value to any public official ... with intent (A) to influence any official act; or (B) to influence such public official ... to commit or aid in committing, or collude in, or allow, any fraud, or make opportunity for the commission of any fraud, on the United States; or (C) to induce such public official ... to do or omit to do any act in violation of the lawful duty of such official or person . . . shall be fined under this title." 18 U.S.C. \& 201(b); see United States v. Rooney, 37 F.3d 847, 852 (2d Cir. 1994) ("[A] fundamental component of a corrupt act is a breach of some official duty owed to the government or the public at large.") (internal quotation marks omitted); see also United States v. Zacher, 586 F.2d 912, 915 (2d Cir. 1978) ("The common thread that runs through common law and statutory formulations of the crime of bribery is the element of corruption, breach of trust, or violation of duty.").

20. United States v. Liebo, 923 F.2d 1308 (8th Cir. 1991).

21. See Thomas R. Snider \& Won Kidane, Combating Corruption Through International Law in Africa: A Comparative Analysis, 40 CorNell INT'L L.J. 691, 721 (2007).

22. Liebo, 923 F.2d at 1311.

23. Id. at 1312. 
purpose of accomplishing either an unlawful end or result, or a law-

ful end or result by some unlawful method or means. ${ }^{24}$

The Eighth Circuit held that "the instructions as a whole adequately instructed the jury that a gift or gratuity does not violate the [FCPA] unless it is given corruptly." 25

\section{b. "Anything of Value"}

"The term anything of value has been defined primarily by case law." 26 Federal courts have consistently given broad meaning to the phrase anything of value in interpreting federal criminal statutes. ${ }^{27}$ It is important for companies to recognize that there does not have to be a direct monetary benefit to the foreign official for an FCPA violation to occur. ${ }^{28}$ "Items found to be of value include the following: money; gifts; discounts; use of resources (materials, facilities, and equipment); entertainment; luxuries (food, travel, meals, lodging); promises for future employment; and insurance benefits." 29

\section{c. "Knowledge" Requirement}

The knowledge requirement, in respect to conduct, is met when that person is aware or has a firm belief that he or she is making an improper payment. ${ }^{30}$ The knowing standard is broad and does not necessarily require actual knowledge. ${ }^{31}$ The legislative history of the FCPA shows that recklessness is not enough for the knowledge requirement; however, "willful blindness" will be seen as meeting the knowledge requirement. ${ }^{32}$

24. Id. (internal quotation marks omitted).

25. Id. (internal quotation marks omitted).

26. See Ned Sebelius, Foreign Corrupt Practices Act, 45 AM. CRIM. L. Rev. 579,588 n.61 (2008) (internal quotation marks omitted).

27. See, e.g., United States v. Gorman, 807 F.2d 1299, 1305 (6th Cir. 1986); see also J $\mathrm{J}_{\mathrm{AY}}$ Grenig et AL., 2 FED. Jury Prac. \& INSTR. $\$ 27.10$ (6th ed.) (“'[A]nything of value' means any item, whether tangible or intangible, that the person giving or offering or the person demanding or receiving considers to be worth something ... [i]nclud[ing] a sum of money, favorable treatment, a job, or special consideration.").

28. See Rollo C. Baker, Foreign Corrupt Practices Act, 47 AM. Crim. L. Rev. 647, 658-59 \& n.68 (2010).

29. $I d$. at 658 (internal quotation marks omitted).

30. See 15 U.S.C. $\S 78 \mathrm{dd}-1$ (f)(2)(A)(i)-(ii) (2006)

31. United States v. Reyes, 302 F.3d 48, 54 (2d Cir. 2002) (finding that the defendant has sufficient knowledge of the conspiracy even though he consciously avoided actual knowledge of the purposes and objectives of the conspiracy).

32. See H.R. REP. No. 100-576, at 919 (1988) (Conf. Rep.), reprinted in 1988 U.S.C.C.A.N. $1,547,1,952-53$ (noting that the knowing standard includes "both prohibited actions that are taken with actual knowledge of intended results as well as other actions that, while falling short of what the law terms positive knowledge, nevertheless evidence a conscious disregard or delib- 


\section{d. "Foreign Official"}

The term "foreign official" is defined in the FCPA as "any officer or employee of a foreign government or any department, agency, or instrumentality thereof, or of a public international organization, or any person acting in an official capacity for or on behalf of any such government or department." 33 This term has recently been challenged in regard to whether the FCPA applies to officers and employees of state-owned entities (SOEs). ${ }^{34}$ The defendants in these cases argue that the plain language and legislative history of the statute with regard to "instrumentality" excludes SOEs. ${ }^{35}$ In Aguilar, U.S. District Judge Howard Matz denied the defendants' motion to dismiss, concluding that employees of SOEs can be foreign officials for purposes of the FCPA. ${ }^{36}$ In Carson, U.S. District Judge James Selna denied the defendants' motion to dismiss and stated that the "ordinary meaning of instrumentality indicates that state-owned companies could fall under the ambit of the FCPA. Whether such companies do, in fact, qualify as an instrumentality is a question of fact." 37 The court listed a number of factors to determine whether a business entity constitutes a government instrumentality, including "(1) the foreign state's characterization of the SOE and its employees; (2) the degree of control by the foreign state; (3) the purpose of the entity's activities; and (4) the extent of government ownership, including level of financial support."38

The DOJ has also recently provided guidance on who qualifies as a foreign official. In the recently released Resource Guide to the U.S.

erate ignorance of known circumstances that should reasonably alert one to the high probability of violations of the [FCPA]" (internal quotation marks omitted)).

33. 15 U.S.C. $\$ 78 \mathrm{dd}-1(f)(1)(A)$.

34. See generally United States v. Carson, No. SACR 09-00077-JVS, 2011 WL 5101701 (C.D. Cal. May 18, 2011); United States v. Aguilar, 783 F. Supp, 2d 1108 (C.D. Cal. 2011).

35. Carson, 2011 WL 5101701, at *4, *7; Aguilar, 783 F. Supp. 2 d at 1110 n.3. For an in-depth analysis of whether an employee of a state-owned corporation can be prosecuted for a violation of the FCPA, see U.S. Dep't of Justice, FCPA Opinion Procedure Release No. 10-03 (Sept. 1, 2010), available at http://www.justice.gov/criminal/fraud/fcpa/opinion/2010/1003.pdf.

36. See Aguilar, 783 F. Supp. 2d at 1115 (holding that a state-owned corporation could have been an instrumentality of a foreign government within the meaning of the FCPA). Officers of such a state-owned corporation, as two employees were alleged to be, could have been foreign officials within the meaning of the FCPA. See id.; see also Steven Mikulan \& Aruna Viswanatha, Judge Upholds DOJ Definition of "Foreign Official", MAIN JUSTICE: Just ANTI-Corruprion (Apr. 1, 2011), http://www.mainjustice.com/justanticorruption/2011/04/01/judge-upholds-doj-definition-of-foreign-official/.

37. Carson, 2011 WL 5101701, at *10 (internal quotation marks omitted).

38. See Paul T. Friedman et al., FCPA Update: Another Challenge to DOJ's Expansive "Foreign Official" Definition Fails, but Clarifies DOJ's Burden, MORRISON FOERSTER, 2 (June 2, 2011), http:/www.mofo.com/files/Uploads/Images/110602-FCPA-Update.pdf. 
Foreign Corrupt Practices Act, the DOJ states that "the FCPA broadly applies to corrupt payments to any officer or employee of a foreign government and to those acting on the foreign government's behalf." 39 The guide also states that "[t]he term instrumentality is broad and can include state-owned or state-controlled entities. Whether a particular entity constitutes an instrumentality under the FCPA requires a fact-specific analysis of an entity's ownership, control, status, and function." 40 As a guide, companies can assume that, based upon the guidance provided by the DOJ, "an entity is unlikely to qualify as an instrumentality if a government does not own or control a majority of its shares." 41

The FCPA also includes certain public international organizations. Under the FCPA, a public international organization is defined as (1) "an organization that is designated by Executive order pursuant to section 1 of the International Organizations Immunities Act" or (2) "any other international organization that is designated by the President by Executive order for the purposes of this section, effective as of the date of publication of such order in the Federal Register."42 "Currently, only eighty-three organizations have such designation by executive order." 43 The inclusion of public international organizations is particularly important in the context of charitable giving because organizations such as the International Committee of the Red Cross, the United Nations, and the World Health Organization are subject to FCPA enforcement. ${ }^{44}$

39. U.S. Dep't of Justice \& U.S. Sec. \& Exch. Comm'n, A Resource Guide to the U.S. Foreign Corrupt Practices ACt 20 (2012) (internal quotation marks omitted), available at http://www.sec.gov/spotlight/fcpa/fcpa-resource-guide.pdf.

40. Id. (internal quotation marks omitted). For examples of jury instructions relating to what factors courts look at to determine government ownership, see Jury Instructions and Order at 5 , United States v. Esquenazi, No. 1:09-cr-21010-JEM (S.D. Fla. Aug. 5, 2011), ECF No. 309; Carson, 2011 WL 5101701; and Aguilar, 783 F. Supp. 2d at 1115.

41. U.S. Dep't of Justice \& U.S. SeC. \& ExCH. Comm'N, supra note 39, at 21. However, practitioners must be aware that the resource guide also comments on situations where this will not be true. "[A] French issuer's three subsidiaries were convicted of paying bribes to employees of a Malaysian telecommunications company that was $43 \%$ owned by Malaysia's Ministry of Finance. There, notwithstanding its minority ownership stake in the company, the Ministry held the status of a 'special shareholder,' had veto power over all major expenditures, and controlled important operational decisions." Id.

42. 15 U.S.C. \& 78dd-1(f)(1)(B)(i)-(ii) (2006).

43. F. Joseph Warin et al., The British Are Coming!: Britain Changes Its Law on Foreign Bribery and Joins the International Fight Against Corruption, 46 TEX. INT'L L.J. 1, 19 (2010).

44. See 22 U.S.C. $\$ 288$. 


\section{e. "Obtain or Retain" Business}

Under 15 U.S.C. $\$ 78 \mathrm{dd}-1(\mathrm{a})(1)(\mathrm{B})$, a violation of the FCPA occurs only if a payment is made to obtain or retain business. The courts have interpreted this statute very broadly; for instance, the Fifth Circuit has found that it applies to obtaining favorable rulings on tax legislation. ${ }^{45}$

\section{Record-Keeping Provisions}

The FCPA books and records and internal controls provisions (record-keeping provisions) ${ }^{46}$ apply only to issuers registered under the Securities Exchange Act of 1934 (the Exchange Act) ${ }^{47}$ and issuers that are required to file reports under 15 U.S.C. $\$ 78$ o(d). ${ }^{48}$ Because only issuers are subject to the requirements of the record-keeping provisions, they are not as widely applicable as the anti-bribery provisions. ${ }^{49}$ The record-keeping provisions mandate accountability for the disposition of assets and transactions of issuers. ${ }^{50}$ In addition, the issuer must have acted knowingly to be liable under the record-keeping provisions. ${ }^{51}$

\section{Exceptions and Affirmative Defenses}

The sole exception to the FCPA covers payments made to foreign officials to secure performance of a "routine governmental action." 52 The FCPA defines a routine governmental action as one that is ordinarily and commonly performed by a foreign official in:

(i) obtaining permits, licenses, or other official documents to qualify a person to do business in a foreign country;

(ii) processing governmental papers, such as visas and work orders;

(iii) providing police protection, mail pick-up and delivery, or scheduling inspections associated with contract performance or inspections related to transit of goods across country;

45. See United States v. Kay, 359 F.3d 738, 748 (5th Cir. 2004) (holding that prohibition against payments to foreign officials to obtain or retain business "was sufficiently broad to include bribes meant to affect administration of revenue laws").

46. See 15 U.S.C. $\$ 78 \mathrm{~m}(\mathrm{~b})(2)-(7)$.

47. Id. $\& 78 \mathrm{a}$.

48. Id. (concerning the registration and regulation of brokers and dealers).

49. Robin Miller, Annotation, Construction and Application of Foreign Corrupt Practices Act of 1977, 6 A.L.R. FED. 2d 351 (2005).

50. 15 U.S.C. $\$ 78 \mathrm{~m}(\mathrm{~b})(2)(A)$.

51. See United States v. Jensen, 532 F. Supp. 2d 1187, 1195 (N.D. Cal. 2008) ("Congress merely intended to protect parties who inadvertently violate the Books \& Records statute. As a result, a person can be criminally convicted for a Books \& Records violation if the government proves that they acted willfully - that is, knowing the falsification to be wrongful, 15 U.S.C. $\$ 78 f f(a)$-and acted knowingly - that is, deliberately and not by accident.").

52. See Baker, supra note 28 , at 662 . 
(iv) providing phone service, power and water supply, loading and unloading cargo, or protecting perishable products or commodities from deterioration; or

(v) actions of a similar nature..$^{53}$

However, the routine governmental action exception excludes:

any decision by a foreign official whether, or on what terms, to award new business to or to continue business with a particular party, or any action taken by a foreign official involved in the decision-making process to encourage a decision to award new business to or continue business with a particular party. ${ }^{54}$

The affirmative defenses to the FCPA include payments made that are legal under the written laws of the foreign official's country and payments that are reasonable and bona fide expenditures. ${ }^{55}$ The first affirmative defense-payments legal under the written laws of the foreign official's country-can be raised only when the written laws in a foreign official's country authorize the payment; the defense may not be based on practice or custom. ${ }^{56}$ To assert the affirmative defense of payments that are reasonable and bona fide expenditures, the payment must be directly related to "the promotion, demonstration, or explanation of products or services" or "the execution or performance of a contract with a foreign government or agency thereof." 57 The company charged with an FCPA violation must affirmatively plead the defenses and show that its payment met the requirements. ${ }^{58}$

\section{Enforcement and Penalties}

The DOJ and the SEC share the enforcement powers for the antibribery and record-keeping provisions..$^{59}$ The DOJ is responsible for all criminal and civil enforcement (except with respect to registrants) of the anti-bribery provisions, as well as criminal enforcement of the record-keeping provisions. ${ }^{60}$ The SEC is responsible for civil enforcement of both the anti-bribery and the record-keeping provisions with

53. 15 U.S.C. $\$ 78 \mathrm{dd}-1(\mathrm{f})(3)(\mathrm{A})(\mathrm{i})-(\mathrm{v})$.

54. $I$ d. $\S 78 \mathrm{dd}-1(\mathrm{f})(3)(\mathrm{B})$.

55. Id. $\S 78 \mathrm{dd}-1(\mathrm{c})(1)-(2)$.

56. See H.R. REP. No. 100-576, at 922 (1988) (Conf. Rep.), reprinted in 1988 U.S.C.C.A.N. $1,547,1,955$ ("[A] payment to a foreign official is lawful under the written laws and regulations of the foreign official's country. (emphasis added). The Conferees wish to make clear that the absence of written laws in a foreign official's country would not by itself be sufficient to satisfy this defense." (internal quotation marks omitted)).

57. 15 U.S.C. $\& 78 \mathrm{dd}-1$ (c)(2)(A)-(B).

58. See McSorley, supra note 5 , at 765 n.108.

59. John P. Giraudo, Charitable Contributions and the FCPA: Schering-Plough and the Increasing Scope of SEC Enforcement, 61 Bus. LAw. 135, 141 (2005).

60. See Foreign Corrupt Practices Act Amendments, Pub. L. No. 100-418, § 5003, 102 Stat. $1,107,1,416-17$ (1988) (codified at 15 U.S.C. $\S \S 78 d d-1$ to $78 d d-3$ ). 
respect to registrants. ${ }^{61}$ There is considerable overlap, and the two enforcement agencies often collaborate on investigations. ${ }^{62}$ The critical distinction between the record-keeping provisions and the antibribery provisions is the absence of any requirement of knowledge or intent in the record-keeping provisions in order for the government to prove a civil case. ${ }^{63}$

The law imposes criminal and civil penalties on individuals and companies for FCPA violations. 64 A company that commits a criminal violation of the anti-bribery provisions may be fined up to $\$ 2$ million per violation and is subject to civil penalties of $\$ 10,000$ per violation. ${ }^{65}$ Civil violations of the record-keeping provisions can lead to injunctions, the disgorgement of profits, and other remedies. ${ }^{66}$

\section{Charitable Giving And the FCPA}

Corporate philanthropy is very important in the global marketplace. William Ford, Jr., former CEO of Ford Motor Company, once said that the distinction between a good company and a great company is that "a good company delivers excellent products and services, a great one delivers excellent products and services and strives to make the world a better place." 67 Many companies seek to be good corporate citizens through gifts to charity and social responsibility projects. ${ }^{68}$ The FCPA has implications for corporate charitable giving and social responsibility projects that many multinational companies engage in throughout the world. ${ }^{69}$

\section{A. In re Schering-Plough}

The only case to date of an action brought against a company for charitable donations under the FCPA is SEC v. Schering-Plough

61. See id.

62. Giraudo, supra note 59 , at 141.

63. Id. at 142 .

64. E.g., Justin Serafini, Foreign Corrupt Practices Act, 41 Am. Crim. L. Rev. 721, 738-39 (2004).

65. 15 U.S.C. $\S 78 f f(c)(1)(A)-(B)$.

66. See generally 18 U.S.C. $\$ 3571$ (setting out alternative fines).

67. William Clay Ford, Jr., Chairman's Message: Ford in the 21st Century, WILEy (Mar. 11, 1999), http:/www.wiley.com/college/kieso/0471363049/dt/analysttool/realco/ford/chairman.htm.

68. Faith Stevelman Kahn, Pandora's Box: Managerial Discretion and the Problem of Corporate Philanthropy, 44 UCLA L. REv. 579, 587 (1997) ("Corporate charitable contributions amount to several billion dollars in aggregate on an annual basis.").

69. See Dan Kadlec, Charitable Giving: How Companies Are Doing More with Less, TIME (June 5, 2012), http://business.time.com/2012/06/05/charitable-giving-how-companies-are-doingmore-with-less/ (noting that "[t]he median level of corporate giving was $\$ 24.4$ million in $2011 "$ "). 
Corp. ${ }^{70}$ The SEC alleged that Schering-Plough Corp. ${ }^{71}$ violated the record-keeping provisions of the FCPA. ${ }^{72}$ Without admitting or denying the SEC's allegations, Schering-Plough Corp. consented to a judgment by the United States District Court for the District of Columbia that required Schering-Plough Corp. to pay a $\$ 500,000$ civil penalty. ${ }^{73}$

In February 1999, Schering-Plough Poland (S-P Poland) ${ }^{74}$ made a zł3,000 (approximately \$777) payment to the Chudow Castle Foundation (Foundation). ${ }^{75}$ The founder and president of the Foundation was the director of the Silesian Health Fund. ${ }^{76}$ In 2000, the director of the Silesian Health Fund solicited S-P Poland to make additional payments to the Foundation. ${ }^{77}$ Between March 2000 and March 2002, S-P Poland's oncology unit manager arranged for twelve additional payments to the Foundation; some payments were structured so that they were under the manager's approval limit, apparently for the purpose of obscuring the nature of the payments. ${ }^{78}$ The manager also "provided false medical justifications for most of the payments on the documents that he submitted to [S-P Poland's] finance department."79

The SEC found that between February 1999 and March 2002, S-P Poland paid zł315,800 $(\$ 75,860)$ to the Foundation. ${ }^{80}$ S-P Poland paid more money to the Foundation than to any other recipient of promo-

70. See Complaint, SEC v. Schering-Plough Corp., No. 1:04CV00945, 2004 WL 2057340 (D.D.C. June 9, 2004) [hereinafter Schering-Plough Complaint].

71. Schering-Plough Corp. "is a New Jersey corporation with its headquarters in Kenilworth, New Jersey. Its common stock is registered with the [SEC] pursuant to Section 12(b) of the Exchange Act and is listed on the New York Stock Exchange." Id. II 3.

72. Id. II 2. The complaint specifically alleged that Schering-Plough Corp. violated sections 13(b)(2)(A) and 13(b)(2)(B) of the Exchange Act. Id. III 14-15.

73. In re Schering-Plough Corp., Exchange Act Release No. 2032, 2004 WL 1267922 (June 9, 2004). Schering-Plough also agreed to hire an independent consultant to review and evaluate Schering-Plough's internal controls, record-keeping, and financial reporting policies and procedures as they related to the company's compliance with the FCPA. Id. at *4-5. The independent consultant would be required to issue periodic reports to the SEC on the measures being implemented as related to Schering-Plough's compliance with the FCPA. Id.

74. "Schering-Plough Poland ('S-P Poland'), headquartered in Warsaw, Poland, is a branch office of Schering-Plough Central East AG, a wholly owned subsidiary of Schering-Plough Corp. that is headquartered in Lucerne, Switzerland." Id. at *1.

75. Id. at *2. "Chudow Castle Foundation ('Foundation') is a charitable organization that was established in 1995 to restore castles and other historic sites in the Silesian region of Poland." In re Schering-Plough Corp., 2004 WL 1267922, at*1.

76. Id. "The Silesian Health Fund was a government body that ... provided monies for the purchase of pharmaceutical products and influenced the purchase of those products by other entities, such as hospitals, through the allocation of health fund resources." Id. at *2. It is one of sixteen regional government health authorities in Poland. Id. at *1.

77. Schering-Plough Complaint, supra note 70, II 7.

78. Id.

79. Id.

80. See id. 
tional donations. ${ }^{81}$ "During 2000 and 2001, the payments to the Foundation constituted approximately $40 \%$ and $20 \%$, respectively, of S-P Poland's total promotional donations budget." 82 Even more unusual was the fact that the Foundation was the only recipient of multiple donations. ${ }^{83}$

The SEC also found that "[a]11 of the payments to the Foundation were classified by S-P Poland in its books and records as donations. However, while the payments in fact were made to a bona fide charity, they were made to influence the Director [of the Silesian Health Fund] with respect to the purchase of [S-P Poland's] products." 84 "During the period in which the payments were being made to the Foundation, S-P Poland's sales of Intron A and Temodal, two of its oncology products, increased disproportionately compared with sales of those products in other regions of Poland." 85 The oncology unit manager did not view the payments as charitable, "but as dues that were required to be paid for assistance from the Director [of the Silesian Health Fund]." 86

The SEC also found that prior to March 2002, Schering-Plough Corp.'s policies and procedures for detecting possible FCPA violations by its foreign subsidiaries were inadequate. ${ }^{87}$ The policies and procedures did not require employees to conduct any investigation or due diligence prior to making charitable donations to determine whether government officials were affiliated with the recipients, and for this reason, the director of the Silesian Health Fund's relationship was never considered by S-P Poland as a potential FCPA issue. 88

The SEC found that Schering-Plough Corp. should have been alerted to the fact that there were FCPA issues relating to S-P Poland's donations to the Foundation because (1) "the Foundation [was] not a healthcare related entity, yet still received payments;" 89 (2) the proportion of the payments to the Foundation in relation to the company's budget for charitable donations; (3) the structuring of the payments by the oncology unit manager that apparently allowed him to

81. Id. II 8 .

82. Schering-Plough Complaint, supra note 70 , II 8.

83. Id.

84. Id. II 9.

85. Id. \10.

86. Id. II 9.

87. In re Schering-Plough Corp., Exchange Act Release No. 2032, 2004 WL 1267922, at *1, *3 (June 9, 2004).

88. Id. at *3.

89. Id. S-P Poland's internal policies provided that promotional donations generally were supposed to be made to healthcare institutions and relate to the practice of medicine. Id. at *3 n.5. 
exceed his authorization limits; and (4) the president of the Foundation was the director of the Silesian Health Fund, who had the ability to influence the purchase of S-P Poland's products by hospitals within the Silesian Health Fund. ${ }^{90}$

Schering-Plough is significant for a number of reasons. It is the only case to date where a company was charged with an FCPA violation for making contributions to a charitable organization. ${ }^{91}$ The case suggests that companies could be held liable for FCPA violations if they fail to install internal controls to analyze links between government officials and the activities of their foreign subsidiaries, including when making charitable contributions. ${ }^{92}$ The case is also significant because the Polish government official did not personally benefit from the payments; all of the donated funds went to the Foundation. ${ }^{93}$ The SEC took the view that regardless of whether the Polish government official personally benefitted from the payments, the payments were still improper because of his relationship to the Foundation..$^{94}$ The case also evidences a critical distinction between the enforcement authority of the SEC and the DOJ under the FCPA ${ }^{95}$ : the SEC does not need to prove bribery to bring an action against a company under the record-keeping provisions of the FCPA. ${ }^{96}$

Schering-Plough involved payments being made by a foreign subsidiary of a U.S. company. ${ }^{97}$ The SEC found that Schering-Plough Corp.'s policies for detecting possible violations by its foreign subsidiaries were inadequate. ${ }^{98}$ This finding is very important, especially with the number of multinational corporations who have subsidiaries in different countries throughout the world. ${ }^{99}$ The FCPA imposes the duty to implement internal controls directly on the parent company, allowing the SEC to hold the parent company responsible for any inadequate internal controls at a subsidiary that failed to prevent and detect improper payments. ${ }^{100}$

90. See Schering-Plough Complaint, supra note 70, $\mathbb{} 13$.

91. Giraudo, supra note 59, at 151 .

92. See id. at 136.

93. Id. at 151.

94. Id.

95. $I d$. at 136 .

96. Giraudo, supra note 59 , at 136 .

97. See generally In re Schering-Plough Corp., Exchange Act Release No. 2032, 2004 WL 1267922 (June 9, 2004).

98. Id.

99. See List of Multinational Corporations by Country, INvesTMENTS \& INCOME, http://www. investmentsandincome.com/investments/list_mnc_by_country.html (last visited May 14, 2013).

100. Internal Control Failures Lead to Parent Liability for a Subsidiary's FCPA Violations, Shearman \& Sterling LLP (June 2, 2009), http://www.shearman.com/files/Publication/ad3385 
Schering-Plough raises many additional questions concerning the scope of FCPA enforcement in regard to charitable contributions. How will the rationale from Schering-Plough be applied to other cases of charitable giving? What if, instead of the president, the Polish government official had just been a member of the board of directors for the Foundation? What if the Polish government official had no association with the charity, but his spouse or child was a member of the board of directors of the Foundation? What if, instead of the director of the Silesian Health Fund, the Polish government official was Minister of Education or Minister of Finance?

Under the facts of Schering-Plough, because of the way the payments were structured and reported, it probably would not have made a difference whether the Polish government official served as a board member rather than the president of the Foundation or even if it was a family member who served as a board member of the Foundation. ${ }^{101}$ The Polish government official was still able to influence the hospital's purchasing decisions within the Silesian Health Fund. If, instead of the director of the Silesian Health Fund, the Polish government official were Minister of Education or Minister of Finance, the payments would probably not have violated the FCPA. ${ }^{102}$ If the Polish government official did not have the influence over the purchasing of S-P Poland's products, and the payments were not made to gain an improper advantage, the payments to the Foundation would not have violated the FCPA.

\section{B. Wynn Resorts}

In February 2012, after an investigation by former Nevada Governor Robert Miller and Louis Freeh, the ex-director of the Federal Bureau of Investigation, Wynn Resorts Ltd. Director Kazuo Okada was asked to resign based upon allegations that Okada violated U.S. anticorruption laws by making cash payments and gifts worth about $\$ 110,000$ to foreign gambling regulators. ${ }^{103}$ Earlier, in January 2012, Okada had "sued Wynn in Nevada seeking information about a $\$ 135$ million donation to the University of Macau, among other things. Okada called the donation inappropriate because the final installment

96-312b-4c83-af02-e5ac48d0ce9e/Presentation/PublicationAttachment/32b60431-2eb2-48d3-8fb 2-08f843854e2d/FCPA-060209-Internal-Control-Failures-Lead-to-Parent-Liability-for-a-Subsidiary.pdf.

101. See Giraudo, supra note 59, at 152.

102. See id.

103. Dan Hart, Wynn Resorts Redeems Director Okada's Stake After Probe, BloombeRG BusINESSWEEK (Feb. 21, 2012), http://www.businessweek.com/news/2012-02-21/wynn-resorts-redeems-director-okada-s-stake-after-probe.html. 
is due in ten years, when Wynn Macau's gaming license is set to expire." 104

On February 8, 2012, following Mr. Okada's lawsuit, the Company received a letter from the Salt Lake Regional Office of the [SEC] requesting that, in connection with an informal inquiry by the SEC, the Company preserve information relating to the donation to the University of Macau, any donations by the Company to any other educational charitable institutions, including the University of Macau Development Foundation, and the Company's casino or concession gaming licenses or renewals in Macau. ${ }^{105}$

In its February 2012 SEC filing, Wynn Resorts stated that the donation "was consistent with the Company's long-standing practice of providing philanthropic support" and was made only after "an extensive analysis which concluded that the gift was made in accordance with all applicable laws."106 However, a Wall Street Journal article reported that the board of the university foundation includes "current and former government officials" and "a member of the committee to elect Macau's chief executive," who is the chancellor of the university. ${ }^{107}$

Even though case law reflects that there is no private cause of action for an FCPA claim, ${ }^{108}$ the Wynn situation emphasizes that FCPA investigations can spawn from unrelated civil ligation. This example reflects the importance of adequate controls as to charitable donations, which are discussed in detail in this Article. ${ }^{109}$

\section{DOJ FCPA Opinion Procedure Releases}

The DOJ has issued multiple FCPA Opinion Procedure Releases (FCPA Opinions) ${ }^{110}$ concerning whether charitable contributions

104. Richard L. Cassin, Wynn Resorts Boots Non-Compliant Director, Shareholder, THE FCPA BLOG (Feb. 20, 2012, 2:28 AM), http://www.fcpablog.com/blog/2012/2/20/wynn-resortsboots-non-compliant-director-shareholder.html.

105. Wynn Resorts, Ltd., Current Report (Form 8-K) (Feb. 13, 2012).

106. Id.

107. Kate O'Keeffe \& Alexandra Berzon, Macau School Ties Roil Wynn Resorts, WALL ST. J. (Mar. 2, 2012, 2:23 AM), http://online.wsj.com/article/SB10001424052970204571404577253232255 305166.html.

108. See, e.g., Lamb v. Phillip Morris, Inc., 915 F.2d 1024, 1030 (6th Cir. 1990).

109. See infra Part V(A).

110. See 15 U.S.C. \& 78dd-1(e)(1) (2006) ("The Attorney General, after consultation with appropriate departments and agencies of the United States and after obtaining the views of all interested persons through public notice and comment procedures, shall establish a procedure to provide responses to specific inquiries by issuers concerning conformance of their conduct with the Department of Justice's present enforcement policy regarding the preceding provisions of this section."). 
made by companies would violate the FCPA. ${ }^{111}$ The FCPA Opinions state whether or not certain specified prospective conduct would violate the current provisions of the FCPA. ${ }^{112}$ It is important to note that "[t]he entire transaction which is the subject of the request must be an actual-not a hypothetical-transaction but need not involve only prospective conduct. However, a request will not be considered unless that portion of the transaction for which an opinion is sought involves only prospective conduct." 113

It is also important to note that "an FCPA Opinion will not bind or obligate any agency other than the [DOJ]. It will not affect the requesting issuer's or domestic concern's obligations to any other agency, or under any statutory or regulatory provision other than those specifically cited in the particular FCPA Opinion." 114

An FCPA Opinion will state only the Attorney General's opinion as to whether the prospective conduct would violate the [DOJ's] present enforcement policy under [the FCPA]. If the conduct for which an FCPA Opinion is requested is subject to approval by any other agency, such FCPA Opinion shall in no way be taken to indicate the [DOJ's] views on the legal or factual issues that may be raised before that agency, or in an appeal from the agency's decision. ${ }^{115}$

For example, if a company requests an FCPA Opinion on a proposed action, the company could still face civil or criminal charges brought by another government agency or jurisdiction even if the DOJ decides not to take action. ${ }^{116}$ In the context of the FCPA, it would most likely be the SEC bringing a claim under the FCPA; it is important to note that the SEC has a lower burden of proof for prosecuting an FCPA violation. ${ }^{117}$

111. See generally Opinion Procedure Releases, U.S. Dep'T of Jusrice, http://www.justice.gov/ criminal/fraud/fcpa/opinion/2010/1003.pdf (last visited May 14, 2013). Since 1993, the DOJ has issued thirty-six Opinion Procedure Releases. See id. Five of these opinions discuss the FCPA implications of prospective charitable contributions. See id. These five opinions are discussed at length in the body of this Article.

112. See 28 C.F.R. $\$ 80.1$ (2012) (noting that the FCPA Opinion Procedure allows "issuers and domestic concerns to obtain an opinion of the Attorney General as to whether certain specified, prospective-not hypothetical-conduct conforms with the Department's present enforcement policy regarding the antibribery provisions of the [FCPA]").

113. Id. $\$ 80.3$.

114. Id. $\S 80.11$.

115. Id. $\$ 80.13$.

116. See id.

117. See Giraudo, supra note 59 , at 136. 


\section{FCPA Opinion Procedure Release 95-01}

The DOJ received a request by a U.S.-based energy company. ${ }^{118}$ The energy company planned to acquire and operate a plant in a country in South Asia that lacked modern medical facilities in the region where the plant was located. ${ }^{119}$ A modern medical complex was under construction near the plant and its costs of the medical facility were projected to run in excess of $\$ 100$ million. ${ }^{120}$ Once the acquisition of the plant was completed, the energy company planned to donate $\$ 10$ million to the medical facility for "construction and equipment" costs. 121

The donation would be made through a charitable organization incorporated in the United States and through a public limited liability company located in the South Asian nation (foreign PLLC). ${ }^{122}$ The energy company represented that it would "require certifications from all officers of the [U.S. charity] and the [foreign PLLC] that none of the funds will be used, promised or offered in violation of the FCPA." 123 The energy company also represented that none of the persons employed by or acting on behalf of the charity or foreign PLLC were affiliated with the South Asian government. ${ }^{124}$ In addition, the energy company represented that it would require audited financial reports from the U.S. charity, accurately detailing the dispersal of the donated funds. ${ }^{125}$ Based upon these facts, the DOJ did not intend to take any enforcement action with respect to the prospective donation for the construction and equipment of the medical facility described in the request. ${ }^{126}$

\section{FCPA Opinion Procedure Release 97-02}

The DOJ received a request by a U.S.-based utility company. ${ }^{127}$ The utility company had begun construction of a plant in an Asian country that lacked adequate education facilities in the region. ${ }^{128}$ An elementary school was being built near the location of the plant, and

118. U.S. Dep't of Justice, FCPA Opinion Procedure Release No. 95-01 (Jan. 11, 1995), available at http://www.justice.gov/criminal/fraud/fcpa/opinion/1995/9501.pdf.

119. Id.

120. $I d$.

121. Id.

122. Id.

123. FCPA Opinion Procedure Release No. 95-01, supra note 118.

124. Id.

125. Id.

126. $I d$.

127. U.S. Dep't of Justice, FCPA Opinion Procedure Release No. 97-02 (Nov. 5, 1997), available at http://www.justice.gov/criminal/fraud/fcpa/opinion/2007/1102.pdf.

128. Id. 
the costs to build the school were projected to exceed $\$ 100,000.129$ The utility company intended to donate $\$ 100,000$ to the school construction project; the donation would be made "directly to the government entity responsible for the construction and supply of the proposed elementary school." 130

The utility company represented that it would "require a written agreement from the government entity that the funds would be used solely to construct and supply the elementary school."131 The written agreement would set forth other conditions to be met, including "guaranteeing the availability of land, teachers, and administrative personnel for the school [and] guaranteeing timely additional funding of the school project in the event of any financial shortfall."132 Based upon the fact that the donation would not be given to any specific foreign official but, instead, would be made directly to a government entity, the DOJ opined that the FCPA did not appear to apply to the proposed donation and that it did not intend to take any enforcement action with respect to the prospective donation. ${ }^{133}$

\section{FCPA Opinion Procedure Release 06-01}

The DOJ received a request by a Delaware corporation headquartered in Switzerland (Delaware Corporation). ${ }^{134}$ The Delaware Corporation sought to "contribute $\$ 25,000$ to a regional Customs department of the Ministry of Finance [(Ministry)] in an African country as part of a pilot project to improve local enforcement of anticounterfeiting laws."135 The Delaware Corporation sought to make the monetary contribution to the Ministry in order for the agency to "fund incentive awards to local customs officials to improve local enforcement relating to seizures of counterfeit products bearing the trademarks of the [Delaware Corporation] and its competitors."136

According to the Delaware Corporation, a transit tax was collected on all goods transiting the country, even those that were contraband or counterfeit. ${ }^{137}$ The salaries of local customs officials include a small percentage of any transit tax they collect, regardless of whether they

129. Id.

130. Id.

131. $I d$

132. FCPA Opinion Procedure Release No. 97-02, supra note 127.

133. Id.

134. U.S. Dep't of Justice, FCPA Opinion Procedure Release No. 06-01 (Oct. 16, 2006), available at http://www.justice.gov/criminal/fraud/fcpa/opinion/2006/0601.pdf.

135. Id.

136. Id.

137. Id. 
were authentic or counterfeit products, meaning that "there [was] a financial disincentive for thorough inspection by local customs officials of goods."138

The Delaware Corporation represented that in connection with the $\$ 25,000$ contribution, it would execute a formal memorandum of understanding (MOU) with the Ministry to "encourage the mutual exchange of information related to the trade of counterfeit products" and establish procedures for incentive programs for local customs officials who seize counterfeit products. ${ }^{139}$ The Delaware Corporation also represented that it would establish "procedural safeguards designed to assure that the funds made available by the [Delaware Corporation's] contribution were, in fact, going to . . local customs officials for the purposes intended." 140 The Delaware Corporation also represented that it would monitor the incentive program and take no part in choosing which customs officials received the incentive award. ${ }^{141}$

The Delaware Corporation represented that its pending business activities in the African country were relatively small and unrelated to its request for an FCPA Opinion and further represented that its future business in the African country was not dependent upon the donation to the customs program and that the donation was not intended to influence any foreign official to obtain or retain business. ${ }^{142}$ Based upon these facts, the DOJ did not intend to take any enforcement action with respect to the prospective donation; however, the FCPA Opinion included two caveats. ${ }^{143}$ The caveats stated that the FCPA Opinion should not be deemed to endorse the language used in the MOU and that the FCPA Opinion did not "apply to any monetary payments made by the [Delaware Corporation] for purposes other than those expressed in the letter of request."144

\section{FCPA Opinion Procedure Release 09-01}

The DOJ received a request by a U.S. company that designs and manufactures medical devices. ${ }^{145}$ In March 2009, representatives of the U.S. company visited a foreign country to meet with a senior offi-

\footnotetext{
138. Id.

139. FCPA Opinion Procedure Release No. 06-01, supra note 134.

140. Id.

141. Id.

142. $I d$.

143. $I d$.

144. FCPA Opinion Procedure Release No. 06-01, supra note 134.

145. U.S. Dep't of Justice, FCPA Opinion Procedure Release No. 09-01 (Aug. 3, 2009), available at http://www.justice.gov/criminal/fraud/fcpa/opinion/2009/0901.pdf.
} 
cial of a government agency (Senior Official). ${ }^{146}$ During the visit, the Senior Official explained that the government intended to "purchase the medical devices, and then subsidize the cost of such devices when it resells them to patients." 147 The Senior Official informed the U.S. company that all manufacturers would be allowed to participate in tenders for government purchases of the medical devices, but it would only "endorse products that it ha[d] technically evaluated with favorable results." 148

Because the foreign government was not familiar with the U.S. company's devices, the Senior Official asked the U.S. company to provide free sample devices to government health centers for testing. ${ }^{149}$ The U.S. company was also to provide accessories for the medical devices free of charge, as well as follow-up support; the approximate value of the devices and related items and services was about $\$ 1.9$ million. ${ }^{150}$

The recipients for the sample devices were to be selected from a list of candidates-provided by the participating medical centers-by a working group of health care professionals who were experienced with that specific type of medical device. ${ }^{151}$ The U.S. company's country manager in the foreign country, who was a physician, would "participate in the working group that evaluates and selects patients who will receive the donated devices;"152 it was also noted that the country manager had received FCPA training in January 2008 and March 2009.

To ensure fairness and transparency in the selection process, the names of the recipients would be published. ${ }^{153}$ Further, the close family members of the foreign government agency's officers or employees, working group members, or employees of the health centers who would be participating in the selection process or in testing and evaluating the medical devices

will be ineligible to be recipients under the program unless (a) the government-employed relatives of such recipient hold low-level positions and are not in positions to influence either the selection or testing process; (b) the government-employed relatives of such recipient clearly meet the requisite economic criteria; and (c) the re-

146. $I d$.

147. Id.

148. $I d$.

149. Id.

150. FCPA Opinion Procedure Release No. 09-01, supra note 145.

151. Id.

152. Id.

153. Id. 
cipient is determined to be a more suitable candidate than candidates who were not selected based on technical criteria. ${ }^{154}$

The evaluation of the donated medical devices would be based on objective criteria, and the U.S. company represented that it had no reason to believe that the Senior Official, who suggested providing the devices, would personally benefit from the donation of the devices. ${ }^{155}$ Based upon the fact that the donation would be made directly to a government entity, and not to any specific foreign official, the DOJ opined that the FCPA did not appear to apply to the proposed donation and that it did not intend to take any enforcement action with respect to the prospective donation. ${ }^{156}$

\section{FCPA Opinion Procedure Release 10-02}

The DOJ received a request by a U.S.-based microfinance institution (USMFI) whose mission was to provide loans and basic financial services to low-income entrepreneurs. ${ }^{157}$ USMFI was "in the process of converting all of its local operations to commercial entities that [were] licensed as financial institutions, in order to permit them to attract capital and expand their services."158 One of the operations was a wholly owned subsidiary in a country in Eurasia (Eurasian Subsidiary) that was overseen by an agency of the Eurasian country (Regulating Agency). ${ }^{159}$

The Eurasian Subsidiary had been "seeking to transform itself from its ... status as an institution regulated by the Regulating Agency into an entity that would [have permitted] it to apply for regulation by the Central Bank of the Eurasian country, with the ultimate goal of acquiring a license as a bank." 160 The Regulating Agency had taken a skeptical view of such transitions, expressing concern that allowing microfinance institutions (MFIs) to "transition from humanitarian status (under which MFIs cannot distribute dividends to shareholders) to commercial status could result in grant funds and their proceeds that originally were intended for humanitarian assistance in the Eurasian country either being withdrawn from the country or being used to benefit private investors." 161

154. Id.

155. FCPA Opinion Procedure Release No. 09-01, supra note 145.

156. Id.

157. U.S. Dep't of Justice, FCPA Opinion Procedure Release No. 10-02 (July 16, 2010), available at $\mathrm{http}: / / \mathrm{www}$.justice.gov/criminal/fraud/fcpa/opinion/2010/1002.pdf.

158. Id.

159. Id.

160. Id.

161. Id. 
The Regulating Agency insisted that the Eurasian Subsidiary make a grant to a local MFI in an amount equal to approximately one third of the Eurasian Subsidiary's original grant capital. ${ }^{162}$ The Regulating Agency provided a list of local MFIs in the Eurasian country and stated that the Eurasian Subsidiary could not fulfill its localization obligation unless it provided grant funding to one or more of the institutions listed. ${ }^{163}$

USMFI was concerned that compelled grants to a specified institution, without appropriate safeguards, raised red flags under the FCPA. ${ }^{164}$ USMFI resisted the Regulating Agency's efforts to compel it to make such grants, but the Regulating Agency rejected alternate proposals as inconsistent with its policy. ${ }^{165}$ The Regulating Agency did state that the "Eurasian Subsidiary could engage in due diligence of the local MFIs and could . . . impose controls on the use of grant funds." 166

The Eurasian Subsidiary undertook a three-stage due diligence process to select the proposed grantee. ${ }^{167}$ First, "it conducted an initial screening of ... potential grant recipients by obtaining publicly available information and information from third-party sources."168 Second, it "request[ed] and review[ed] key operating and assessment documents for each organization, as well as conducted interviews with representatives of each MFI to ask questions about each organization's relationships with the government . . to elicit information about potential corruption risk." 169 Third, it "identif[ied] any ties to specific government officials, determine[d] whether the organization had faced any criminal prosecutions or investigations, and assess[ed] the organization's reputation for integrity."170 The third round of due diligence uncovered that one of the board members for the selected MFI was a sitting government official in the Eurasian country. ${ }^{171}$ However, the sitting government official served in a capacity that was completely unrelated to the microfinancing industry, and under the law of the Eurasian country, sitting government officials may not be compensated for that type of board service. ${ }^{172}$ The proposed grant

162. FCPA Opinion Procedure Release No. 10-02, supra note 157.

163. Id.

164. $I d$.

165. $I d$.

166. $I d$.

167. FCPA Opinion Procedure Release No. 10-02, supra note 157.

168. Id.

169. $I d$.

170. $I d$.

171. $I d$.

172. FCPA Opinion Procedure Release No. 10-02, supra note 157. 
was also subject to significant controls proposed by USMFI, including staggered payment of grant funds, ongoing monitoring and auditing, earmarked funds for capacity-building, prohibition on compensating board members, and anti-corruption policy provisions. ${ }^{173}$

The DOJ found that the Eurasian Subsidiary's proposed grant to the local MFI was for the purpose of obtaining or retaining business in the Eurasian country - the proposed grant "would be made as a condition precedent to obtaining a license to operate as a financial institution."174 The real issue was whether the proposed grant would amount to the "corrupt giving of anything of value to any officials of [the Eurasian] country in return for obtaining or retaining business."175 The DOJ further found that based on the due diligence that was done and with the benefit of the controls that would be put into place, it was unlikely that the payment would result in the corrupt giving of anything of value to such officials. ${ }^{176}$ The DOJ also referenced FCPA Opinions 95-01, 97-02, and 06-01 in its discussion to illustrate the due diligence and controls required to avoid violating the FCPA when making a charitable contribution. ${ }^{177}$

\section{What We Have Learned}

It is instructive to look at the FCPA Opinions to see when the DOJ will take action on companies' charitable contributions. By examining the FCPA Opinions, there are four main areas of concern for the DOJ when deciding whether or not to take enforcement action on a proposed charitable contribution. The first area of concern is if any official of the charity is affiliated with the foreign government where the payment is being made. The second area of concern is whether the payment is being made to a foreign official or, instead, is being given directly to a foreign government entity. The third area of concern is the level of control and monitoring a company plans to implement once it makes the payment. The final area of concern is whether there is a "compelled giving" law that mandates a company to make a contribution to the community where it is investing or conducting business. It is important to note that these areas of concern will often overlap.

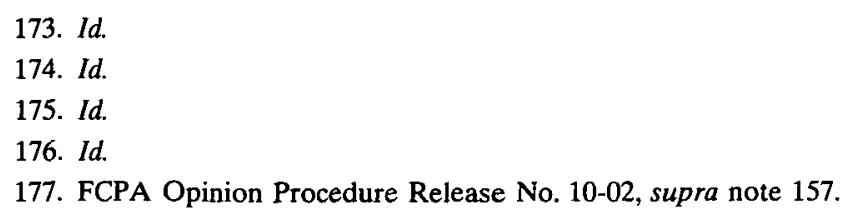


1. No Officials of the Charity Affiliated with Foreign Government

The risk of an FCPA violation is reduced if a company makes the payment to a charitable organization that is not affiliated with a foreign government or foreign official. In FCPA Opinion 95-01, the U.S.based energy company certified that it had conducted an investigation and represented that "none of the persons employed by or acting, on behalf of the charitable organization or the limited liability company are affiliated with the foreign government." 178 However, this is not always the end of the analysis.

For example, assume you are a medical device manufacturer. You are selling medical devices in an African country and are approached by the director of a hospital in the African country who proposes, that by donating money to the local charity that provides healthcare for low income families, he will make sure that his hospital and all other hospitals in the region will buy your company's medical devices. You have completed due diligence and found that there are no government officials employed by the charity or serve on its board of directors. Under this set of facts, there would not be an FCPA violation because you are donating money to a charity at the request of a private company, i.e. the hospital. ${ }^{179}$ However, now assume that the hospital is run by the state. Under this set of facts, there may be a violation of the FCPA. You would be donating money to a charity to influence the hospital's decision on which products to buy. Remember that there does not have to be a direct monetary benefic to the government official or employee of an SOE for an FCPA violation to occur. ${ }^{180}$ The donation is also being made to gain an improper business advantage in the African country. A court would look at the factors, including the foreign state's characterization of the SOE, the degree of control by the foreign state, the purpose of the entity's activities, and the extent of government ownership. ${ }^{181}$ Based upon the answers to these inquiries, the medical device manufacturer may violate the FCPA by making the donation to the charity at the request of the director of the stateowned hospital.

178. FCPA Opinion Procedure Release No. 95-01, supra note 118.

179. This hypothetical is derived from the facts in FCPA Opinion Procedure Release No. 9501. See id.

180. "Although not defined within the FCPA or legislative history, the DOJ, SEC, and the courts have interpreted anything of value expansively." Baker, supra note 28 , at $658-59$ (internal quotation marks omitted).

181. See United States v. Carson, No. SACR 09-00077-JVS, 2011 WL 5101701, at *3, *4 (C.D. Cal. May 18, 2011). 
It is also routine practice for companies to employ the use of consultants and agents in a foreign country. ${ }^{182}$ This can be very cost effective for companies; the consultants and agents have a good working knowledge of local customs and the local business system. However, there are also situations where companies utilize consultants and agents to make payments to foreign charities; this situation will be discussed later in the Article. ${ }^{183}$

\section{Payments Made Directly to Foreign Government}

If a company makes the payments directly to a foreign government entity, they are outside the scope of the FCPA. In FCPA Opinion 9702 , the DOJ stated that "[a]s the requestor's donation will be made directly to a government entity-and not to any foreign government official- the provisions of the FCPA do not appear to apply to this prospective transaction." 184 In FCPA Opinion 06-01, the DOJ stated that "the proposed provision of 100 medical devices and related items and services fall outside the scope of the FCPA in that the donated products will be provided to the foreign government, as opposed to individual government officials." 185

By analyzing these FCPA Opinions, it is reasonable to assume that the DOJ will not take action on donations made by companies directly to a foreign government agency. However, these FCPA Opinions are troublesome in that they seem to give companies room to circumvent the FCPA. Assume you are counsel to a U.S. mining company. The company plans to donate $\$ 50,000$ for the construction of a hospital. The director of the foreign government entity that grants mining contracts assures the U.S. company that it will receive certain mining contracts, which it would normally have had to bid on, by making the contribution. The charitable contribution is being made directly to the foreign government entity that is completing the construction of the hospital. The U.S. company is making the donation specifically to secure certain mining contracts in the foreign country. Would this contribution be a violation of the FCPA?

The U.S. mining company is making a charitable contribution to obtain mining contracts upon which it would otherwise have to bid; however, the contribution is being made directly to a foreign govern-

182. Priya Cherian Huskins, FCPA Prosecutions: Liability Trend to Watch, 60 STAN. L. Rev. 1447, 1455 (2008).

183. See infra Part IV(B)(4).

184. FCPA Opinion Procedure Release No. 97-02, supra note 127.

185. FCPA Opinion Procedure Release No. 06-01, supra note 134. 
ment entity. ${ }^{186}$ The U.S. mining company will argue that because the charitable contribution payment was made directly to a foreign government entity and that because it was properly recorded, there should be no FCPA liability. However, it can be argued that the foreign government official is still receiving a benefit because the donations were subjectively valued by the official and provided him with an intangible benefit of enhanced prestige. ${ }^{187}$ Companies must be aware that, even though the charitable contribution is given directly to a foreign government entity, they may still be held liable for an FCPA violation.

\section{Control and Monitoring of Charitable Contributions}

If the company making the payment represents that there will be ongoing control and monitoring of the payment once it has been made, the DOJ appears to be less likely to take enforcement action. In FCPA Opinion 95-01, the U.S.-based energy company stated it would require "audited financial reports from the U.S. charitable organization, accurately detailing the disposition of the donated funds." 188 In FCPA Opinions 97-02 and 06-01, the DOJ did not take action, in part, because there was a written agreement with the recipient of the payment restricting the use of funds. ${ }^{189}$ Companies must be aware that by having a strong FCPA compliance and training program and performing due diligence, they can greatly reduce the chance of an FCPA violation. This issue will be discussed in further detail later in the Article. ${ }^{190}$

\section{4. "Compelled Giving" Laws}

In FCPA Opinion 10-02, the requesting company was being forced by a foreign government agency to make a grant to a local institution to ensure its grant capital remained in the Eurasian country. ${ }^{191}$ The

186. See, e.g., FCPA Opinion Procedure Release No. 97-02, supra note 127; see also FCPA Opinion Procedure Release No. 06-01, supra note 134.

187. See Mike Koehler, A Double Standard? Part III, FCPA Professor Blog (Sept. 30, 2010, 5:11 AM), fcpaprofessor.blogspot.com/2010/09/double-standard-part-iii.html ("S-P Poland's bona fide charitable donations constituted a thing of value to the foreign official because the donations were subjectively valued by the official and provided him with an intangible benefit of enhanced ... prestige." (internal quotation marks omitted)).

188. FCPA Opinion Procedure Release No. 95-01, supra note 118.

189. See FCPA Opinion Procedure Release No. 97-02, supra note 127; see also FCPA Opinion Procedure Release No. 06-01, supra note 134.

190. See infra Part V(B).

191. See FCPA Opinion Procedure Release No. 10-02, supra note 157. 
foreign government agency also limited the number of entities that could receive the grant. ${ }^{192}$

These "compelled giving" laws are not altogether uncommon. In Venezuelan energy service contracts with the national oil company, Petróleos de Venezuela S.A. (PDVSA), the law requires that the foreign company agree to invest an established percentage of the profits from each contract into the community in which it operates. ${ }^{193}$ The amount of the investment is negotiated with the Venezuelan government and can include cash or in-kind contributions of computers, equipment, or appliances to schools, communities, or organizations. ${ }^{194}$ Although legal and a practice required by law in Venezuela, these payments have generated some questions with regards to compliance with the FCPA and similar laws of other countries. ${ }^{195}$ While not a payment to a governmental official, it is still a payment to a governmental entity for the purpose of securing a contract. ${ }^{196}$ Further, it is possible that a governmental official sits on the board of the local charity in question; this may be present in contracts for infrastructure opportunities, including communications and transportation services. ${ }^{197}$ Other countries, including Nigeria and Angola, have laws mandating foreign companies to enter into contracts that require them to partner with local businesses in order to obtain licenses or conduct business. ${ }^{198}$ Reports from TRACE International also show that public officials routinely ask companies operating in Ukraine for targeted

192. Id.

193. Thomas Fox, Compelled Giving and the FCPA, INFOSEC IsLAND (Aug. 2, 2010), https:// www.infosecisland.com/blogview/6026-Compelled-Giving-and-the-FCPA.html.

194. Id.

195. See Thomas Fox, Plotting a Steady Course in Venezuelan Business, Latin Lawyer, July 16,2010 , at 2 ("While not a payment to a governmental official, it is still a payment to a governmental body for the purpose of securing a lucrative contract and, as such, requires careful consideration.").

196. In two FCPA Opinions, the payment was being made directly to a foreign government or foreign government agency. See FCPA Opinion Procedure Release No. 97-02, supra note 127; FCPA Opinion Procedure Release No. 06-01, supra note 134.

197. In two FCPA Opinions, the U.S. companies requesting DOJ guidance were involved in infrastructure projects in the foreign country. See FCPA Opinion Procedure Release No. 97-02, supra note 127; FCPA Opinion Procedure Release No. 06-01, supra note 134.

198. Richard Craig Smith et al., DOJ Issues FCPA Guidance on Government-Compelled Grants, FULBRIGHT \& JAWORSKI L.L.P. (July 30, 2010), http://www.nortonrosefulbright.com/us/ knowledge/publications/93903; see also Angola: Investment Climate Statement for 2012, EMBAsSY OF THE U.S.: LUANDA, ANGL., http://angola.usembassy.gov/pol-econ-section/investment-climatestatement-2010.html (last visited May 15, 2013) ("In the oil and diamond sectors, contracts with the government spell out the commitments companies make to invest in infrastructure and social services to benefit local communities, such as building schools, equipping hospitals, or funding microcredit programs."). 
corporate charitable donations. ${ }^{199}$ To give insight on the compelled giving issue, Congress specifically stated that " $[\mathrm{t}] \mathrm{he}$ defense that the payment was demanded on the part of a government official as a price for gaining entry into a market or to obtain a contract would not suffice since at some point the U.S. company would make a conscious decision whether or not to pay a bribe."200

In FCPA Opinion 10-02, the DOJ did not intend to take action because of the due diligence completed by USMFI, including research on the list of companies provided by the foreign government agency, staggering the payment of grant funds, ongoing monitoring and auditing, and anti-corruption compliance provisions. ${ }^{201}$ But what if USMFI had not undertaken such rigorous due diligence? What if USMFI had not been allowed to select from a group of local businesses but, instead, was forced to donate to a local business designated by the foreign government agency? If USMFI was then charged with violating the FCPA, could it plead the affirmative defense that the payment was required under the written laws of the foreign official's country?202 Companies should be aware of the distinction between custom and written laws because only the latter is an affirmative defense against an FCPA claim. ${ }^{203}$ Any time that a government agency directs business to a specific entity, local or not, companies should be wary of the FCPA.

\section{Corporate Social Responsibility}

Corporate social responsibility (CSR) ${ }^{204}$ has been debated as long as corporations have existed. "For centuries legal, political, social,

199. See Charitable Contributions in Kiev, TraCE Blog (July 16, 2009), http://traceblog.org/ 2009/07/16/charitable-contributions-in-kiev/ ("While the donations seem to be made transparently and to legitimate, bona fide organizations, the fact that the official initiated the request for the donation and received a personal benefit (even if not a direct, monetary benefit) clearly warrants serious FCPA scrutiny.").

200. S. REP. No. 95-114, at 10 (1977), reprinted in 1977 U.S.C.C.A.N. 4,098, 4,108.

201. FCPA Opinion Procedure Release No. 10-02, supra note 157.

202. It is important to remember that this is not an exception; it must be affirmatively pled by a party charged with an FCPA violation. See 15 U.S.C. $\S 78 \mathrm{dd}-1$ (c)(1) (2006).

203. U.S. Sec. \& Exch. Comm'n, Investor Bulletin: The Foreign Corrupt Practices Act-Prohibition of the Payment of Bribes to Foreign Officials 2 (Oct. 2011), available at https://www.sec.gov/investor/alerts/fcpa.pdf ("In relying on the local law of the foreign country as an affirmative defense for a payment, gift, offer, or promise of anything of value to a foreign official, the law or regulation being relied upon, at the time of the conduct, must be written. Local practice, custom, or other unwritten policies do not qualify as an affirmative defense." (internal quotation marks omitted)).

204. Corporate responsibility is the idea that a corporation takes responsibility for its actions concerning effects on the environment and society. See Thomas McInerney, Putting Regulation Before Responsibility: Towards Binding Norms of Corporate Social Responsibility, 40 CORNELL 
and economic commentators have debated CSR ad nauseam."205 It is a debate of continued relevance with the rapid growth of multinational corporations. According to Merrick Dodd, a former Harvard Law School Professor, "[B]usiness is permitted and encouraged by the law primarily because it is of service to the community rather than because it is a source of profit to its owners."206 Thus, corporations do not exist simply to increase the bottom line but to improve the general welfare of society as well. ${ }^{207}$

However, a company's pursuit to become a good corporate citizen can lead to unintended consequences. When does the pursuit of a CSR program expose a company to liability under the FCPA? Also, what effect does the FCPA have on a company's decision to make charitable donations in certain parts of the world? These are questions that plague companies regardless of their size or the industry in which they operate.

\section{A. The FCPA's Effect on Charitable Contributions}

The FCPA can have a tremendous effect on the amount and recipients of charitable contributions provided by companies. In a speech on September 17, 2008, Bill Reinsch, President of the National Foreign Trade Council, opined that the SEC enforcement actions against Schering-Plough Corp. and others threatened with prosecutions involving bona fide charitable contributions have cast a chilling effect on CSR. 208

Transparency International publishes a Corruption Perceptions Index (the Index) that shows the perceived levels of corruption in each

INT'L L.J. 171, 172 (2007) ("CSR is an umbrella term that refers to a variety of initiatives ranging from voluntary codes of conduct to programs whereby companies can undergo external audits to verify the adequacy of their practices in a variety of areas of social concern. Although generally lacking formal state power of sanction, these efforts look to international law for their normative authority, intending to apply sometimes-latent international legal prescriptions directly to corporations." (footnote omitted)).

205. Henry N. Butler \& Fred S. McChesney, Why They Give at the Office: Shareholder Welfare and Corporate Philanthropy in the Contractual Theory of the Corporation, 84 CORNell L. Rev. 1195, 1195 (1999).

206. E. Merrick Dodd, Jr., For Whom Are Corporate Managers Trustees?, 45 HaRv. L. Rev. 1145, 1149 (1932).

207. See William T. Allen, Our Schizophrenic Conception of the Business Corporation, 14 Cardozo L. Rev. 261, 265 (1992).

208. Bill Reinsch, President, Nat'l Foreign Trade Council, The Impact of Corruption on Global Businesses (Sept. 17, 2008), available at http://www.nftc.org/newsflash/newsflash.asp? Mode=view\&articleid=1987\&Category=All. But see NFTC Criticizes Broadening FCPA Enforcement, Lawyers Disagree, INSIDE U.S. TRADE, Oct. 24, 2008, at 2 (opining that ScheringPlough was "not a harbinger of 'super aggressive cases' to come on charitable contributions"). 
country. ${ }^{209}$ The Index ranks the countries by their level of perceived corruption in order from least to most corrupt. Companies should be aware of the level of corruption in the country where the charitable donation is being made. ${ }^{210}$ For example, a company making a charitable contribution in Venezuela will generally have a more onerous duty of due diligence than a company making a donation to a charitable organization in Denmark. ${ }^{211}$

The amount of perceived corruption in a country can affect a company's willingness to make charitable contributions in that country. For example, after the recent earthquake in Haiti, many companies were reluctant to invest in rebuilding Haiti because of the level of corruption present in the country. A March 2010 Wall Street Journal article quoted an American entrepreneur, who does business in the Caribbean, saying that "the [FCPA] precludes legitimate U.S. entities from entering the Haitian market. Haiti is pure pay to play." 212 In March 2010, Tyler Cowen, the Holbert C. Harris Chair of Economics at George Mason University, suggested that the U.S. needed to pass a law mandating that the FCPA would not apply to payments or investment in Haiti. ${ }^{213}$

These are just a few examples of how the FCPA affects companies' charitable contributions in countries that have high levels of perceived corruption.
A 2009 Dow Jones Risk Compliance survey, announced in a press release entitled "Confusion About Anti-corruption Laws Leads Companies to Abandon Expansion Initiatives," found that $51 \%$ of companies had delayed a business initiative as a result of the FCPA and $14 \%$ had abandoned an initiative altogether. More recently, a 2011 survey by the accounting firm KPMG found that among execu- tives surveyed in the United States and United Kingdom, "more than $70 \% \ldots$ agreed there are places in the world where business cannot be done without engaging in bribery and corruption," and

209. See generally Corruption Perceptions Index 2012, TransPaRenCY INT'L, http://transparency.org/cpi2010/results (last visited May 15, 2013).

210. Neither the DOJ nor the SEC has advised companies to consult the Index list before making a payment or donation in a foreign country; however, companies should still be aware of the perceived corruption in countries where they conduct business.

211. See Corruption Perceptions Index 2012, supra note 209 (showing that on a scale where number 1 is the least perceived corrupt, Denmark is ranked number 1 and Venezuela is ranked 165).

212. Mary Anastasia O'Grady, Democrats and Haiti Telecom, WALl ST. J. (Mar. 15, 2010), http://online.wsj.com/article/SB10001424052748703625304575116030721437698.html.

213. Tyler Cowen, One of the Best Ways to Help Haiti: Modify FCPA, Marginal RevoluTION (Mar. 15, 2010, 9:24 AM), http://marginalrevolution.com/marginalrevolution/2010/03/oneof-the-best-ways-to-help-haiti.html. 
that approximately $30 \%$ of the respondents indicated that they deal with this risk by not doing business in certain countries. ${ }^{214}$

In the context of charitable contributions, it is also important to note that the term foreign official includes certain international organizations. ${ }^{215}$ The International Committee of the Red Cross, the World Health Organization, the United Nations, and the Global Fund to Fight AIDS, Tuberculosis, and Malaria are all organizations subject to the provisions of the FCPA. ${ }^{216}$ These organizations accept charitable contributions that are used throughout the world to aid in the recovery of natural disasters or to support those who cannot support themselves. It is important to note that many foreign aid organizations have ties to foreign governments, so companies must always be aware that even if there is not a foreign official directly involved in the transaction, the company may be held liable if it knows that money will be funneled to a foreign official for an improper purpose. ${ }^{217}$

\section{B. Companies Using Corporate Social Responsibility to Disguise Bribery}

This Article has noted that CSR is a major part of companies' business models and programs where companies contribute money and support to charitable organizations in countries throughout the world. But when does a company's philanthropy expose it to civil or even criminal liability? This Article does not intend to deter companies from donating money to charities; instead, its intention is to illustrate situations in which a company could inadvertently run afoul of the FCPA when making charitable contributions and, also, situations in which a company uses CSR to disguise acts of bribery.

\section{1. "Corrupt" Intent}

The intent behind the donation must be researched to determine whether a charitable contribution being made by a company will violate the FCPA. For a charitable contribution to violate the FCPA, it must be given with corrupt intent. ${ }^{218}$ Legislative history is informative on when a payment will be deemed to be given corruptly. The legislative history signifies that Congress viewed the term corruptly to con-

214. Andrew Brady Spalding, Four Unchartered Corners of Anti-Corruption Law: In Search of Remedies to the Sanctioning Effect, 2012 WIS. L. REv. 661, 665-66 (footnote omitted).

215. See 15 U.S.C. $\$ \S 78 d d-1(f)(1)(B), 78 d d-2(h)(2)(B), 78 d d-3(f)(2)(A)(2006)$.

216. See 22 U.S.C. $\$ 288$ (noting that these organizations were designated by executive order).

217. See H.R. REP. No. 100-576, at 920 (1988) (Conf. Rep.), reprinted in 1988 U.S.C.C.A.N. $1,547,1,953$ (noting that the knowing standard, as seen from the legislative history, is very broad and does not necessarily require actual knowledge).

218. See Burns \& Sullivan, supra note 16. 
note an action that was done with a bad intent. ${ }^{219}$ The legislative history also indicates that corruptly connotes an evil motive and purpose. ${ }^{220}$ Congress, in a 1977 House Report, stated that the word corruptly in the FCPA is intended to have the same meaning as in 18 U.S.C. $\S 201$, which is the federal statute criminalizing the bribing of a federal official. 221

It is important to note the distinction between a company providing charitable donations to an organization in the hope of garnering goodwill and a company providing charitable donations to an organization for the sole purpose of obtaining some type of business advantage or concession, such as tax breaks and favorable treatment.222 Companies should not be deterred from making charitable donations based upon an irrational fear of committing an FCPA violation; however, companies must be aware that if they disguise bribery as charitable giving, they could be held liable for an FCPA violation.

\section{Anti-Bribery v. Record-Keeping Provisions}

Companies must be aware of the bifurcated system of enforcement under the FCPA, especially when making charitable contributions. Although a charitable contribution may not be recognized as a bribe, a company may still face consequences depending on how it documents the contribution in its financial records. It is also important to note that the burden of proof is much lower for an action brought by the SEC as opposed to one brought by the DOJ.223

SEC v. NATCO Group, Inc. exemplifies this distinction.224 In NATCO, TEST Kazakhstan, a subsidiary of NATCO, hired both ex-

219. See id.

220. See H.R. ReP. No. 100-576, at 918 ("The House receded to an amended Senate provision which would prohibit payments to any foreign official for the purpose of influencing any act or decision of such foreign official in his official capacity, or inducing such foreign official to do or omit to do any act in violation of the lawful duty of such official. This language conforms to the domestic bribery standard found at 18 U.S.C. 201." (internal quotation marks omitted)).

221. H.R. REP. No. 95-640, at 8 (1977).

222. See 15 U.S.C. $\S 78 \mathrm{dd}-1(\mathrm{a})(1)(B)(2006)$.

223. See Miller, supra note $49, \S 5$ ("The court, in S.E.C. v. McNulty stated that the view that scienter is not a prerequisite to civil liability under 15 U.S.C.A. $\$ 78 \mathrm{~m}$ is supported by the fact that in 1988 , Congress amended 15 U.S.C.A. $\$ 78 \mathrm{~m}(\mathrm{~b})$ to provide that knowing falsification is required before criminal liability shall be imposed." (citation omitted) (internal quotation marks omitted)); Stephen Clayton, Top Ten Basics of Foreign Corrupt Practices Act Compliance for the Small Legal Department, Ass'N OF CoRP. Couns. (June 1, 2011), http://www.acc.com/legalresources/publications/topten/SLD-FCPA-Compliance.cfm (noting that the SEC brings cases under the record-keeping provisions of the FCPA as civil actions so its burden of proof is preponderance of the evidence).

224. Complaint, SEC v. NATCO Grp. Inc., No. 4:10-cv-98, 2010 WL 2003734 (S.D. Tex. Jan. 11, 2010). 
patriates and local Kazakh workers. 225 In 2007, "Kazakh immigration prosecutors conducted audits and claimed that TEST Kazakhstan's expatriate workers were working without proper immigration documentation. The prosecutors threatened to fine, jail or deport the workers if TEST Kazakhstan did not pay cash fines."226 Even though NATCO was "paying extorted immigration fines," the SEC brought a claim under the record-keeping provisions of the FCPA because its "system of internal accounting controls failed to ensure that [it] recorded the true purpose of the payments."227

The SEC enforcement action against Schering-Plough Corp. also illustrates how a company can violate the record-keeping provisions of the FCPA by not accurately reflecting charitable contributions in its financial records. It is important to note that S-P Poland made charitable contributions to a bona fide charitable organization, and it characterized the payments to the Foundation as donations. ${ }^{228}$ However, the way the payments were structured allowed S-P Poland's oncology unit manager to exceed his authorization limits, and he admitted that he did not view the payments as charitable but instead viewed them as dues that were required to be paid for assistance from the director of the Silesian Health Fund. ${ }^{229}$

\section{Contributions to Domestic Charity Involved in Charitable Foreign Activities}

Many charitable organizations in the United States are often involved in charitable projects throughout the world. Many of these charities are involved in projects in the most corrupt countries. What happens to a company that makes a contribution to a domestic charity that uses the contribution to bribe a government official? The FCPA legislative history and case law have shown that a company cannot turn a blind eye once the transaction is finished.230 What then is the level of due diligence needed to avoid an FCPA violation for a dona-

225. Id. II 5 .

226. Id. ๆ 6.

227. SEC Files Settled Civil Action Charging NATCO Group Inc. with Violations of the Foreign Corrupt Practices Act, Litigation Release No. 21,374 (Jan. 11, 2010), available at http://www. sec.gov/litigation/litreleases/2010/lr21374.htm.

228. In re Schering-Plough Corp., Exchange Act Release No. 2032, 2004 WL 1267922, at *2 (June 9, 2004); see supra Part III(C)(2).

229. See In re Schering-Plough Corp., 2004 WL 1267922, at *2.

230. See H.R. REP. No. 100-576, at 919 (1988) (Conf. Rep.), reprinted in 1988 U.S.C.C.A.N. 1,547, 1,952-53; see also United States v. Reyes, 302 F.3d 48, 54 (2d Cir. 2002); United States v. Jacobs, 475 F.2d 270, 287 \& n.37 (2d Cir. 1973) ("The element of knowledge may be satisfied by proof that a defendant deliberately closed his eyes to what otherwise would have been obvious to him."). 
tion to a domestic charity that is involved in foreign charitable activities?

For example, assume you represent a U.S. petroleum company that has multiple projects in Mexico. The company plans to donate $\$ 50,000$ to a domestic charity that provides education to rural towns throughout Mexico. On its face, this action would not seem to violate the FCPA. Although the company does substantial business in Mexico, it does not seem to be making the donation corruptly; there does not seem to be a foreign official involved, and there is no evidence that the company would obtain or retain business by making the donation.

Changing the facts of the hypothetical, you find a document showing that the company has knowledge of the domestic charity spending more funds in certain areas of the country, and consequently, certain legislative members, whose constituents are benefitted by the donations, are influencing the Mexican Energy Agency to award energy contracts to the U.S. petroleum company. This would be a violation of the FCPA. The U.S. petroleum company is being awarded energy contracts without having to engage in the normal bidding process. Certain legislative members are benefitting from having their constituents happy and, therefore, voting for them in elections. The legislative members are also using their official authority to influence the decision making power of the Mexican Energy Agency that grants the energy contracts to the U.S. petroleum company.

As stated above, all of these cases revolve around the issue of intent and whether the charitable contribution is made corruptly. In most cases, the intent of the contribution will be inferred from the facts surrounding the contribution and the behavior of the parties involved. 231

\section{Corporate Social Responsibility Used to Disguise Bribery: Hypothetical Situations}

The grey area of when a donation is made corruptly and instances where companies use CSR to disguise acts of bribery can be illustrated by using several hypothetical situations.

231. See Arthur F. Mathews, Defending SEC and DOJ FCPA Investigations and Conducting Related Corporate Internal Investigations: The Triton Energy/Indonesia SEC Consent Decree Settlements, $18 \mathrm{Nw}$. J. INT'L L. \& Bus. 303, 380 ("Concealment through falsification of books and records can be strong evidence from which corrupt intent can be inferred."). 
Hypothetical $A^{232}$ : You represent a U.S. electronic device manufacturer that has a subsidiary in an African country. One of the managers of the company seeks your legal advice. The African subsidiary has made several large contributions to a charity that provides clean drinking water for people in remote areas of the country. Upon investigation, you discover that the director of the charity is the minister of technology. Upon further investigation, you find that the minister is using his power to influence decisions of local electronic companies regarding which products to buy.

These donations will violate the FCPA. The donations are being made to a charity whose director is a foreign official under the FCPA. The donations are also specifically being made to the charity to influence the decision making of the foreign official and to obtain additional business in the African country. This is probably the most basic and straightforward example of a company using CSR to disguise acts of bribery.

The crux of these cases will be whether the donation is being given corruptly. 233 CSR is a very important part of a company's business, and just because a contribution is made to a charitable organization does not mean that a company should be worried about committing an FCPA violation. The finding of a corrupt payment will be fact specific. ${ }^{234}$ Was the payment made to influence the decision of a foreign official? Was the payment made to the foreign official to obtain or retain business?

Hypothetical B: An international company, headquartered in Delaware (Delaware Company), has offices throughout the world, including a large office in Japan that serves some of the firm's largest clients. Because of the recent earthquake and tsunami, the Delaware Company plans to donate money to the Red Cross relief effort to resupply Japanese citizens and rebuild Japan's infrastructure.

As outside counsel to the Delaware Company, you are being asked to render an opinion on the legality of the donation. On its face, the donation looks permissible; however, the Red Cross is one of the international organizations designated as a foreign official under the FCPA. ${ }^{235}$ Under this set of facts, the payment raises a red flag, but after conducting due diligence, you find that the payment is being

232. Hypothetical $A$ is derived from the facts of the Schering-Plough case. See generally Schering-Plough Complaint, supra note 70.

233. See Mathews, supra note 231.

234. See id.

235. See 22 U.S.C. $\S 288$ (2006). 
given to a bona fide charity and is not being made corruptly or to gain business in Japan. The donation does not appear to violate the FCPA.

Changing the hypothetical, upon investigation, you find that an employee of the Red Cross informed the Delaware Company that by increasing the amount of the donation to the relief effort, the Red Cross employee would use his position to influence the Japanese government to grant the Delaware Company contracts for the rebuilding process. Under this revised set of facts, the donation would violate the anti-bribery provisions of the FCPA. The donation is being made to a foreign official under the FCPA. The donation is also being made corruptly, i.e. to influence the decision making of the Japanese government to gain building contracts. ${ }^{236}$ Companies must be aware that the language of the FCPA states that for a payment to violate the FCPA, it must be made to influence any act or decision by a foreign official in his official capacity or to secure any improper advantage. ${ }^{237}$ In this hypothetical, depending on how the Delaware Company characterized the donation in its accounting records, it could also be held liable under the record-keeping provisions of the FCPA. ${ }^{238}$

Hypothetical C: You represent a U.S. company that has a subsidiary in Indonesia. The CEO of the Indonesian subsidiary comes to you, as counsel for the parent, seeking advice. He tells you that the subsidiary donated a large sum of money to the UN Population Fund, which provides medical care for many Indonesians who cannot afford it otherwise, in order to obtain certain tax breaks by the Indonesian government. 239

Under this set of facts, the donation would be a violation of the anti-bribery provisions of the FCPA. The donation is being made to the UN, which is a foreign official under the FCPA. ${ }^{240}$ The donation is also being made corruptly, i.e. in exchange for certain tax breaks provided by the Indonesian government. It is important to note that the business purpose test under the FCPA is very broad. ${ }^{241}$

Hypothetical D: Assume you represent an international construction company, headquartered in New York (New York Company). The New York Company is interested in participating in the Haiti rebuilding effort; however, it has never conducted business in Haiti.

236. See 18 U.S.C. $\$ 201(b)(1)$.

237. 15 U.S.C. § 78dd-1(a)(1)(A).

238. See United States v. Jensen, 532 F. Supp. 2d 1187, 1195 (N.D. Cal. 2008).

239. Hypothetical $C$ is derived from the facts of Koy. See generally United States v. Kay, 359 F.3d 738 (5th Cir. 2004).

240. See 22 U.S.C. $\S 288$.

241. See Kay, 359 F.3d at 755 (noting that the so-called business purpose test applies to favorable tax rulings and other favorable legislation and regulation). 
The New York Company hires a Haitian consultant that is familiar with the local laws and customs. On its face, the mere fact of hiring the Haitian consultant is not illegal.

Changing the facts of the hypothetical, the Haitian consultant knows that by making donations to the school where the minister of infrastructure's children go to school, the country will give the New York Company favorable treatment and assure the New York Company that it will be awarded with future building contracts in Haiti. Under this set of facts, the New York Company could be held liable for violating the FCPA. Because the New York Company provided the consultant with money to use in acquiring business in Haiti, the New York Company cannot just turn a blind eye to the consultant and argue that it had no knowledge of such improper payments. The legislative history and case law have shown that companies cannot show a conscious disregard or deliberate ignorance of known circumstances that should reasonably alert one to a high probability of FCPA violations. ${ }^{242}$ Because Haiti is perceived as one of the most corrupt countries in the world, ${ }^{243}$ the New York Company should have been aware of the high probability of an FCPA violation when using a Haitian consultant. ${ }^{244}$

Hypothetical $E^{245}$ : Assume you represent an international tobacco company, headquartered in New York (Tobacco Company). The Tobacco Company has a subsidiary in Venezuela. The Venezuelan subsidiary entered into a contract with a Venezuelan charity. The agreement was signed on behalf of the charity by its director, the wife of the then-President of Venezuela. Under the terms of the agreement, the subsidiary would make periodic donations to the charity totaling approximately $\$ 12.5$ million. In exchange, the subsidiary would obtain price controls on Venezuelan tobacco, eliminate controls on retail cigarette prices in Venezuela, obtain tax deductions for the Tobacco Company, and assure the Tobacco Company that Venezuela

242. H.R. REP. No. 100-576, at 920 (1988) (Conf. Rep.), reprinted in 1988 U.S.C.C.A.N. 1,547, 1,953 (noting that the knowing standard includes "both prohibited action taken with actual knowledge of intended results as well as other actions that, while falling short of what the law terms positive knowledge, nevertheless evidence a conscious disregard or deliberate ignorance of known circumstances that should reasonably alert one to the high probability of violations of the [FCPA]" (internal quotation marks omitted)).

243. See Corruption Perceptions Index 2012, supra note 209 (noting that Haiti is number 165 out of 176 countries).

244. See, e.g., id.

245. Hypothetical $E$ is derived from the facts of Lamb v. Phillip Morris, Inc., 915 F.2d 1024 (6th Cir. 1990). 
would not increase existing tax rates applicable to other tobacco companies. 246

Under this set of facts, the donations would violate the FCPA. Even though no foreign official is directly affiliated with the charity, the wife of the President of Venezuela is the director of the charity. The President is using his influence as a government official to grant benefits to the Tobacco Company, which would not have been granted without the donations. The donations here are being made corruptly and to obtain business because they are made in exchange for price controls and tax deductions.

\section{Minimizing Liability}

This Article has established that there are many challenges facing companies that make charitable donations under the FCPA. This part discusses solutions to those challenges so that companies can minimize liability under the FCPA. It will discuss how a strong compliance program and sufficient due diligence can greatly reduce the chance of an FCPA violation.

\section{A. FCPA Compliance Program}

A strong FCPA and anti-corruption compliance program cannot be underestimated. When one looks at the history of FCPA prosecutions brought by both the SEC and DOJ, one observes that the first step taken by the enforcement authority is to examine what type of program a company had in place to monitor and control outside financial payments and internal accounting controls. ${ }^{247}$ The SEC and DOJ have expressed concerns that the failure to implement an effective FCPA compliance program can allow "systemic cracks to form in corporate compliance systems." 248 An FCPA compliance program means "a single, documented, corporate plan designed to reduce the likelihood that the company will engage in violations of the anti-bribery provisions of the FCPA, and to detect such violations and bring them to the attention of senior management, if they occur." 249

To implement an effective FCPA compliance program, a company must compile several basic categories of information concerning its

246. See generally id.

247. See Daniel J. Grimm, The Foreign Corrupt Practices Act in Merger and Acquisition Transactions: Successor Liability and lts Consequences, 7 N.Y.U. J.L. \& Bus. 247, 264-66 (2010).

248. Id. at 268.

249. Id. at 265 n.68 (quoting Daniel L. Goelzer, Designing an FCPA Compliance Program: Minimizing the Risks of Improper Foreign Payments, 18 Nw. J. INT'L L. \& Bus. 282, 282 (1998)) (internal quotation marks omitted). 
activities. The three kinds of basic information that need to be collected are "the risks of FCPA violations, the existing controls, and the resources and commitment available to administer and monitor the program." 250 With this information, the company can identify the goals and objectives it wishes to accomplish through the FCPA compliance program. ${ }^{251}$

Many companies have FCPA and anti-corruption compliance systems in place; 252 however, many of these systems do not provide guidance for situations involving charitable contributions. Traditionally, this has not been an area of concern for deterring corruption. ${ }^{253} \mathrm{Com}-$ panies must be aware that a charitable contribution may seem innocuous at first glance, but it can lead to grave consequences if made illegally. Companies should continually update their compliance programs. Whenever a violation is discovered, "the compliance program should be reviewed with a view to [determine] why the violation occurred and whether changes should be made in the program to prevent a reoccurrence." 254 Companies must also remember that a compliance "program that tries to impose controls on every conceivable activity that might result in misconduct is likely to prove unwieldy and, in the long run, unenforceable."25s

\section{Proposed Model for Charitable Contribution Compliance Programs}

Companies must have a section in their respective FCPA compliance programs devoted specifically to charitable contributions. This Article does not suggest that a company's compliance program can be written to cover every possible situation, but it can be modified to minimize liability in the area of charitable contributions.

\section{a. Elements}

The first step a company must take is to identify charitable contributions as an area of risk in its FCPA compliance program. For exam-

250. Goelzer, supra note 249, at 294.

251. Id.

252. See Michael Volkov, Anti-Corruption Compliance for Medium and Small Companies, WhIte Collar Defense \& Compliance (Apr. 16, 2011, 10:35 PM), http://michaelvolkov.blogspot.com/2011/04/anti-corruption-compliance-for-medium.html (noting that approximately $40 \%$ of Fortune 500 companies do not have an FCPA or anti-corruption compliance program in place).

253. See Michael Volkov, Bribery Risks and Charitable Giving, Corruption, CRIME \& COMPLIANCE (Apr. 18, 2012), http://corruptioncrimecompliance.com/2012/04/bribery-risks-and-charitable-giving/.

254. Goelzer, supra note 249, at 291.

255. Id. 
ple, Det Norske Veritas (DNV), an international foundation headquartered in Oslo, Norway, includes a statement in its Code of Business Conduct concerning charitable contributions. It states, "We shall not use charitable contributions and sponsorships as a subterfuge for bribery. Charitable contributions and sponsorships shall be documented and open for disclosure."256 This statement is a great example of how companies can specifically include charitable contributions in their FCPA and anti-corruption compliance programs. This language will also prevent employees from later stating that they were not aware of a company policy prohibiting this type of activity. ${ }^{257}$

The second element is to stipulate designated levels of approval for charitable contributions and sponsorships and to designate a compliance officer at a sufficiently high management level who is responsible for overseeing the program. ${ }^{258}$ This entails stipulating the amount of company funds that are allocated for donation to charitable organizations, designating which employees have the power to make charitable contributions on behalf of the company, and supplying a list of acceptable charitable organizations that have been researched and approved. This list should be reviewed and updated frequently.

The third element is to implement a pre-donation review system. ${ }^{259}$ This system will review each proposed charitable contribution and require approval before it is made. This will allow companies the benefit of review prior to the contribution being made, rather than having to review the contribution in hindsight. The pre-donation review system should include written provisions to conduct due diligence to ensure that the proposed foreign donee is a bona fide charitable organization. ${ }^{260}$ This due diligence should include obtaining organizational documents, financial statements and tax returns, information about the organization's charitable programs, history, board of trustees, key employees, and the identity and qualifications of the individu-

256. Code of Business Conduct, DNV, http://www.dnv.com/moreondnv/cr/business_ethics/ code_business_conduct.asp (last visited May 15, 2013); see also Anti-Bribery Policy, Tudor Rose INT'L, at 4, http://www.tudor-rose.com/pdf/TRI_anti-bribery_Policy.pdf (last visited May 15, 2013) ("Bribes may even be disguised as charitable donations. Again, for that reason, donations we make are approved by resolution of the Board and recorded. Whilst individuals may of course make personal donations to charity, they should not do so on behalf of the Company without prior approval from the Managing Director.").

257. See H.R. REP. No. 100-576, at 920 (1988) (Conf. Rep.), reprinted in 1988 U.S.C.C.A.N. $1,547,1,953$.

258. See Volkov, supra note 252.

259. See generally Hyperdynamics Corp., Anti-Bribery Policy and Procedures (2013), available at http://files.shareholder.com/downloads/HDY/0x0x527067/2e8db0e7-060f-498a-8e52b8473693581c/Anti_Bribery_Policy_Procedures-2011-2012-Engl.pdf.

260. See id. at 8. 
als administering the grant. ${ }^{261}$ Companies should also not place a de minimis value on which contributions to review; employees could abuse the system by spreading out one large contribution into several smaller contributions that fall under the level for review. ${ }^{262}$

The fourth element is to mandate that any sponsorship agreements be in writing and state the consideration being provided by the company. ${ }^{263}$ The fifth element is to mandate that all records of charitable contributions and sponsorships be maintained, both locally and at the headquarters of the company. ${ }^{264}$ An original record should also be kept electronically to prevent employees from arguing that a document has been lost, misplaced, or destroyed.

The sixth element is for a company to create an electronic database to track charitable contributions. ${ }^{265}$ The information stored in the database will include the branch or subsidiary of the company making the contribution, the name of the employee proposing the charitable contribution, the name of the charitable organization, the location of the charitable organization, the location where the donated funds or products will be used, and the name of the employee who approved the charitable contribution. This will make it easier for companies to monitor charitable contributions and ensure that the donated funds or products are being used for their intended purpose. It will also make it easier for companies to see the areas where charitable contributions are being made and what percentage of the company's total promotional budget is being used. ${ }^{266}$ The database will make internal investigations run more smoothly because the companies will already have all the information related to a particular charitable contribution stored in one location.

The seventh element is for a company to keep a separate ledger account in its accounting records for charitable contributions and

261. The due diligence required to minimize liability under the FCPA for companies making charitable contributions is discussed in Part V(B).

262. See, e.g., Schering-Plough Complaint, supra note $70, \mathbb{I} 7$ (noting that the payments were structured so that they were at or below the manager's approval limit).

263. See, e.g., Cotecna Inspection SA, Business Ethics \& Compliance Code (2d ed. 2006), available at http:/www.cotecna.ch/en/About-Cotecna/ /media/Documents/PDFs/EN/ Cotecna\%20Business\%20Ethics\%20and\%20Compliance\%20Code_EN.ashx; INT'L FED'N OF inspection Agencies, Compliance Code Guidelines on Implementation (4th ed. 2012), available at http:/www.ifia-federation.org/content/wp-content/uploads/Guidelines_to_3rd_ed_ IFIA_Compliance_Code_-_4th_Edition_July_2012.pdf; TransparenCY INT'L UK, ThE 2010 UK Bribery Act Adequate Procedures 16 (2010), available at http:/www.transparency. org.uk/our-work/bribery-act.

264. See Int'L Fed'N of Inspection Agencies, supta note 263.

265. See Gary M. Lawrence, Due Diligence in Business Transactions $\S 12$ (2004).

266. See, e.g., Schering-Plough Complaint, supra note 70, If 8 (noting that payments to the Foundation constituted $40 \%$ of S-P Poland's total promotional budget in 2000 ). 
sponsorships. ${ }^{267}$ In combination with the electronic database, this will enable a company to have separate records of charitable contributions being made by the company and its branches and subsidiaries.

The eighth element is for a company to prepare an annual management statement on all charitable contributions and sponsorships made by the company or on its behalf during that fiscal year. ${ }^{268}$ This would be in addition to the company's annual report and whatever reports they must create by law (e.g. 10-K, 10-Q, etc.).

The ninth and final element is for a company to implement a comprehensive FCPA and anti-corruption training program for all employees. ${ }^{269}$ Training should be given to all employees, but it is particularly important for managers and other employees who have direct decision making power. Also, as noted above, it is important for a company to engage in a review of its compliance program on no less than an annual basis. A company should determine if its overall program is effective both internally and externally. Additionally, a company should assess any new best practices and whether those concepts should be integrated into its FCPA and anti-corruption program. If a company moves into a new business area or a new geographic area, these new risks should be assessed, evaluated, and managed as well.

A U.S. company making charitable contributions in a foreign country should adopt a company-wide compliance and ethics program designed to prevent and address violations of the FCPA. Companies must also include any foreign subsidiaries in a comprehensive FCPA and anti-corruption compliance program. The FCPA imposes the duty to implement internal controls directly on the parent company, allowing the SEC to hold the parent company responsible for any inadequate internal controls at a subsidiary that failed to prevent and detect improper payments. ${ }^{270}$ This is very important, especially with the number of multinational corporations that have subsidiaries in different countries throughout the world. ${ }^{271}$ As noted earlier in this Article, the SEC found that Schering-Plough Corp.'s policies for

267. See Int'l Fed'N of Inspection Agencies, supra note 263 , at 5.

268. See id.

269. Id.

270. See In re Schering-Plough Corp., Exchange Act Release No. 2032, 2004 WL 1267922, at *3 (June 9, 2004).

271. See James K. Jackson, Congressional Research Serv. Report for Congress No. RL32461, OUtsourcing and Insourcing Jobs in the U.S. Economy: Evidence Based on FOREIGN INVESTMENT DATA 4 (May 10, 2012), available at $\mathrm{http}: / / \mathrm{www} . f a s . o r g / \mathrm{sgp} / \mathrm{crs} / \mathrm{misc} / \mathrm{RL} 32$ 461.pdf ("By the end of 2008, there were more than 2,200 U.S. parent companies with more than 26,000 affiliates operating abroad ...."). 
detecting possible violations by its foreign subsidiaries were inadequate. ${ }^{272}$

The U.S. government will take the existence of an FCPA and anticorruption compliance program into account when considering whether to charge a company with FCPA violations and the level of punishment for any substantiated FCPA violations. ${ }^{273}$ However, the mere existence of a program is not enough-it must have teeth and a number of solid measures as delineated above. As Joseph E. Murphy, board member at the Society of Corporate Compliance and Ethics, stated:

Compliance with the FCPA is an area where faint-hearted efforts will likely fail. The [FCPA] provides ambiguous standards and sets thresholds of liability that can come as an unwelcome surprise to the uninitiated. An effective program will be one that educates and motivates the naïve, and uses aggressive management techniques to deter and ferret out willful misconduct such as bribery. ${ }^{274}$

\section{b. Charitable Contributions Compliance Committee}

A company should create a Charitable Contributions Compliance Committee (CCCC) to implement and monitor the charitable contributions section of its FCPA and anti-corruption compliance program. ${ }^{275}$ The CCCC should be led by a representative from the company's law department. It should be a cross-functional group of executives that ensures that all charitable contributions made through any of the company's business units are aligned and in compliance with company policy. ${ }^{276}$ The members of the CCCC must be given specific training concerning charitable contributions as pertaining to the FCPA and must continually attend trainings and seminars to stay abreast of current developments in the area of charitable contributions under the FCPA. They should also meet bimonthly to discuss implementation of compliance and ethics initiatives.

The CCCC should be granted powers to investigate all allegations, ${ }^{277}$ and on a periodic basis, it should provide a report of allega-

272. In re Schering-Plough Corp., 2004 WL 1267922, at *3.

273. See Salen Churi et al., Complying with the Foreign Corrupt Practices Act: A Practical Primer, ABA Crim. Just. Sec. Anti-Corruption Task Force, Jan. 2012, at 23.

274. Ethics Point, Foreign Corrupt Practices Act (FCPA): Managing Risk in a New ERA of ENForCEMENT 4 (2010).

275. For an example of a CCCC, see Corporate Citizenship Governance and Structure, McKESSON, http://2011.mckessoncorporatecitizenship.com/our-company/corporate-citizenship-governance-and-structure (last visited May 15, 2013).

276. $I$.

277. It is imperative for a company to have a system for employees to report violations (anonymously if they wish) of company policies or other suspected illegal or unethical activity. 
tions and investigations to the company's senior management and its board of directors. The CCCC's duties should include the following: reporting to management on compliance matters and program effectiveness; administering a compliance training program; coordinating internal compliance monitoring activities; reviewing complaints, reports, and questions received; coordinating investigations relating to compliance matters; and, where necessary, ensuring that its company takes corrective action. ${ }^{278}$

\section{c. Whistleblower Protection Program}

It is very important for a company to have "an effective internal corporate system for reporting suspected criminal conduct and/or violations of the compliance policies, standards and procedures regarding the FCPA and other applicable anti-corruption laws for directors, officers, employees, and outside agents and business partners." 279 A company should have a strong whistleblower program through the use of a hotline or other appropriate mechanism, a clearly stated policy of protection for any employee who reports such conduct through anonymous reporting, and a clear no-retaliation policy. 280

Internal reporting mechanisms and whistleblower protection programs have become more important in light of the newly enacted Dodd-Frank Wall Street Reform and Consumer Protection Act (the Dodd-Frank Act). ${ }^{281}$ Section 922 of the Dodd-Frank Act specifies that a person who provides to the SEC "original information" of fraud within the company that leads to an enforcement penalty of $\$ 1$ million or more may be entitled to collect between $10 \%$ and $30 \%$ of the penalties enforced. ${ }^{282}$ The provision also provides substantial retaliation protections for whistleblowers. ${ }^{283}$ Companies should be aware of the provisions of the Dodd-Frank Act and structure their FCPA compliance program to reflect these provisions. Many companies will likely have to update their FCPA compliance programs to abide by the Dodd-Frank Act provisions.

278. Corporate Citizenship Governance and Structure, supra note 275.

279. Robert W. Tarun \& Peter P. Tomczak, A Proposal for a United States Department of Justice Foreign Corrupt Practices Act Leniency Policy, 47 AM. CRIM. L. Rev. 153, 219-20 (2010).

280. Lanny A. Breuer, Assistant Attorney Gen., U.S. Dep't of Justice, Prepared Remarks to Compliance Week 2010-5th Annual Conference for Corporate Financial, Legal, Risk, Audit \& Compliance Officers (May 26, 2010), available at $\mathrm{http}: / \mathrm{www}$.justice.gov/criminal/pr/speeches-testimony/2010/05-26-10aag-compliance-week-speech.pdf.

281. Dodd-Frank Wall Street Reform and Consumer Protection Act, Pub. L. No. 111-203, $\S 922,124$ Stat. 1,376, 1,841-42 (2010) (codified at 15 U.S.C.A. $\$ \$ 78 a-78 p p$ (West Supp. 2010)).

282. Id.

283. See id. 


\section{B. Due Diligence}

Even if a company has a strong FCPA and anti-corruption compliance program, it still must exercise due diligence when making charitable contributions. As noted above, compliance programs can minimize liability but not erase it completely. Exercising due diligence is very important when making charitable contributions. The company must look at all the circumstances surrounding the donations and also research the persons involved in the transaction. The due diligence obligation is even more important for companies that make contributions to charities in countries that have high levels of corruption. ${ }^{284}$

Outlined below is a roadmap for what due diligence a company should engage in before making a charitable contribution. ${ }^{285}$ First, a company must research the country where it is making the charitable contribution. As discussed earlier in this Article, the company must be aware of the level of corruption in the country where the charitable contribution is being made. ${ }^{286}$ The company must also conduct due diligence to ensure that the proposed foreign donee is a bona fide charitable organization. ${ }^{287}$ This should include obtaining organizational documents, financial statements and tax returns, information about the organization's charitable programs, history, board of trustees and key employee information, and the identity and qualifications of the individuals administering the contribution.

The company should also require FCPA certifications from the charitable organization. ${ }^{288}$ Before releasing any funds, the charitable organization must certify in writing that none of the donated funds will be used, promised, or offered in violation of the FCPA. ${ }^{289} \mathrm{Be}$ cause of the complexity of the FCPA and the ambiguity of when a payment will be made in violation of the FCPA, these certifications might not have the deterrent effect that a company intended.

Next, a company must confirm that none of the charitable organization's officers or board members is affiliated with the foreign government. The typical situation would be similar to Schering-Plough, where a foreign official was the director of the charitable organization. However, in most cases it will be an indirect link to a foreign official,

284. See Corruption Perceptions Index 2012, supra note 209.

285. See FCPA Opinion Procedure Release No. 10-02, supra note 157 (listing the due diligence and controls implemented by companies in prior FCPA Opinions).

286. See Corruption Perceptions Index 2012, supra note 209.

287. See FCPA Opinion Procedure Release No. 06-01, supra note 134.

288. See FCPA Opinion Procedure Release No. 95-01, supra note 118.

289. See id. 
such as a close relative or family friend, or a contribution made to an international organization recognized as a foreign official under the FCPA. There could also be cases where a high-level employee of a SOE is the director of a charitable organization or on its board of directors. Therefore, as discussed earlier, companies must engage in due diligence when researching a charitable organization's link to a foreign official or foreign government.

Even if a foreign official sits on the board of the charitable organization, it is not necessarily a de facto FCPA violation to make a charitable contribution to that organization. The company must look at whether, under that country's laws, government officials can be compensated for that type of board service and, also, whether the foreign official serves in a capacity related to the business being conducted in that country, allowing the official to create an improper business advantage for the company. ${ }^{290}$

In addition, a company must require the charitable organization to provide audited financial statements that accurately reflect the disposition of the donated funds. This will allow a company to know if the donated funds are being used for their intended purpose. For example, a company might donate money to a charitable organization for building a school; however, based on audited financial reports, it might find that the money was used for a different project or was used in an illegal venture. The company could also use a written agreement, signed by the company and the charitable organization, that restricts the use of the donated funds. For example, in FCPA Opinion 97-02, the U.S. utility company used a written agreement that set forth conditions on how the donated money was to be used.291 In FCPA Opinion 06-01, the Delaware Corporation executed a formal MOU that provided that the charitable organization retain five years of records of the distribution of funds and would permit inspection of those records at the request of the Delaware Corporation. ${ }^{292}$

By completing the necessary due diligence, companies will be in a much better position to avoid FCPA liability when making charitable contributions. Using these steps, companies can identify potential liability issues and create an appropriate due diligence process that is intentional, consistent, and systematic to ensure full transparency and accountability.

290. See, e.g., FCPA Opinion Procedure Release No. 10-02, supra note 157.

291. See FCPA Opinion Procedure Release No. 97-02, supra note 127.

292. See FCPA Opinion Procedure Release No. 06-01, supra note 134. 


\section{Conclusion}

Many companies see philanthropy as an important business practice. Companies seek to be good corporate citizens by making charitable contributions and donating to social responsibility projects such as building schools and hospitals. This is even truer for multinational companies that operate in emerging markets.

The area of charitable contributions under the FCPA is an ambiguous area of the law in which liability for companies can be enormous. ${ }^{293}$ Companies must be aware that they can face liability under the FCPA any time they make a charitable contribution, regardless of whether the contribution is given to a charitable organization in the United States that participates in projects in foreign countries or given directly to a foreign charitable organization. By implementing a strong FCPA and anti-corruption program and by completing sufficient due diligence, a company can greatly minimize its liability before making a charitable contribution.

293. "The U.S. government assessed nearly $\$ 2$ billion in FCPA-related penalties and fines in 2010, and announced eight of the top ten FCPA settlements of all time." See Bethany Hengsbach \& Anthony Navid Moshirnia, 2010 Foreign Corrupt Practices Act "FCPA" Year in Review, NAT'L L. REv. (Feb. 23, 2011), http://www.natlawreview.com/article/2010-foreign-corrupt-practices-act-fcpa-year-review. 